NBER WORKING PAPERS SERIES

\title{
FORWARD INTO THE PAST: PRODUCTIVITY RETROGRESSION IN THE ELECTRIC GENERATING INDUSTRY
}

\author{
Robert J. Gordon
}

Working Paper No. 3988

\author{
NATIONAL BUREAU OF ECONOMIC RESEARCH \\ 1050 Massachusetts Avenue \\ Cambridge, MA 02138 \\ February 1992
}

This research was supported by the National Science Foundation. I am grateful to Thomas Cowing for providing the original pre-1972 data set, to Ross Newman and George Kahn for preliminary work on updating the data, and to Tim Schmidt, Gabriel Sensenbrenner, Dan Shiman, Tim Stephens, Janet Willer, and Gabriel Sensenbrenner for further work on the data and regressions. Victor $\mathrm{Li}$ carried out the final update of the regression results with admirable care and attention to detail. Martin N. Baily, Ernst R. Berndt, Edward F. Denison, Frank M. Gollop, Zvi Griliches, and Ariel Pakes provided helpful suggestions on earlier drafts of the paper. This paper is part of NBER's research program in Productivity. Any opinions expressed are those of the author and not those of the National Bureau of Economic Research. 
NBER Working Paper \#3988

February 1992

\title{
FORWARD INTO THE PAST: PRODUCTIVITY RETROGRESSION \\ IN THE ELECTRIC GENERATING INDUSTRY
}

\begin{abstract}
The electric utility industry is a prime culprit in the U.S. productivity growth slowdown of the last two decades. This paper develops econometric labor and fuel demand equations for a large panel data set covering almost all fossil-fueled electric generating capacity over the period 1948-87. Labor productivity and fuel efficiency both advanced rapidly until the late 1960 s and then both reversed direction, deteriorating substantially. particularly for newly constructed plants.

The research goes beyond econometric estimation by conducting a set of telephone interviews with plant managers of establishments that registered particularly high or low productivity. The interviews reveal many variables and relations that are omitted in conventional econometric studies of production. They support the view that the productivity reversal originated in the manufacturing industry that produces electric generating equipment: after decades of increased scale. temperature. and pressure. a "technological frontier" was reached in which new large plants developed unanticipated maintenance problems requiring substantial additions of maintenance employees. Environmental regulations also contributed to the productivity reversal but were secondary in importance to the technological barriers. Overall. the study supports the "depletion hypothesis" previously advanced to explain the productivity slowdown.
\end{abstract}

Robert J. Gordon Department of Economics Northwestem University Evanston, Il 60208-2600 and NBER 


\section{INTRODUCTION}

The worldwide slowdown in productivity growth since the early 1970 s has continued to puzzle economists. The failure to identify any convincing single cause has led to a shift in research away from aggregate studies toward more detailed research at the industry level. ${ }^{1}$ Along with construction and mining, the electric utility industry is one of three U.S. industries that have suffered the sharpest deceleration of productivity growth and thus is a natural candidate for detailed study.

Three special advantages commend the electric utility industry for analysis. First, its output is unusually homogenous, thus minimizing the usual problem of errors in measuring output. Second, as a regulated industry, the production process of electric utility generation is documented in an unusually detailed body of micro data at the establishment level. Third, electric utilities should be a fertile ground to test several of the most prominent single-cause theories of the aggregate productivity slowdown, including those that emphasize the role of energy prices, capital accumulation, environmental regulation, and the "depletion" of technology.

This paper provides new estimates of factor demand equations for labor and fuel use at the establishment level for fossil-fueled steam-electric generating plants, using a data set that has been newly developed for this study. It attempts to link the results to three strands of literature that have developed largely in isolation, (1) the macro-oriented literature on the economywide productivity slowdown, (2) the industrial organization literature on public

1. Among the single-cause explanations for the aggregate economy are higher energy prices (Rasche-Tatom, 1981), high raw materials prices (Bruno-Sachs, 1985). slower capital accumulation (Norsworthy, Harper. Kunze, 1979), a decline in capital services relative to the measured capital stock (Baily, 1981), and "depletion" of resources and ideas (Nordhaus, 1980, 1982). Others, including Edward Denison (1985). tend to attribute the slowdown to a multitude of causes. 


\section{Productivity in Electricity Generation, Page 2}

utility and environmental regulation, and (3) the econometric literature on production technology and factor demand in the electric utility industry.

Standard econometric methodology is used except in one respect, the treatment of outlier observations. Unlike most panel data sets in which the identity of individual observations is unknown, here it is possible to contact plant managers of individual outlier establishments and identify important determinants of input demand, thus illuminating the role of missing variables or mismeasured data. The summary of the telephone interviews represents an important contribution of the research and adds insight that cannot be provided by the econometric coefficient estimates alone.

\section{ELECTRICITY GENERATION IN THE CONTEXT OF THE ECONOMYWIDE PRODUCTIVITY SLOWDOWN}

The electric utility industry is a prime culprit in the economywide post-1973 productivity growth slowdown. As shown in Table 1, growth in labor productivity (output per bour) in the electric utility industry proceeded at a rate triple that of the aggregate economy from 1899 to 1948 , and at a rate 2.5 times as fast from 1948 to 1973 . After 1973 , however, the previously rapid rate of advance for electric utilities came screeching to a halt, as productivity growth slowed to the same low rate as experienced by the aggregate economy.

Table 1 also displays the growth rate of the real price of electricity over the same time intervals. Here the rate of improvement decelerated sharply immediately after World War II, and the historical decline in the real price was replaced by an increase after 1973. 
The fact that the real price fell so much more before 1948 than after, while growth in labor productivity remained fairly steady through 1973 , suggests that other factors must have made a major contribution to the falling real price before 1948, e.g., a decline in the relative price of fuel and of quality-adjusted capital input. The declining real price of electricity was an important source of productivity growth in the aggregate economy through the early 1970 s, for historically much technical progress has been labor saving and electricity using (Jorgenson, 1984).

A closer look at the postwar period is provided in Table 2, which documents the behavior since 1948 of output and productivity in the public utility sector as defined in the National Income and Products Accounts (NIPA), and in the electric utility portion of the utility sector. Also shown is the relative price of electricity. The top half of the table displays levels of variables, and the bottom half displays annual rates of growth over five year intervals.

Real GNP growth in the utility sector was most rapid before 1953 , reached a plateau between 1953 and 1973, almost ceased between 1973 and 1983, and then revived after 1983. The slowdown in labor productivity growth in the sector began earlier than that of output, and productivity growth was actually negative on average between 1973 and 1983, followed by a revival during 1983-88. Productivity growth for electric utilities in column (4) displays roughly the same pattern as for the utility sector in column (3). The final column shows that the period of rapid productivity growth coincided with that of a decline in the relative price of electricity, and the poor productivity decade of $1973-83$ coincided with the period of most 
rapid increase in the relative price of electricity.

\section{Scope of the Study}

This paper limits its attention to the production of electricity in steam plants using fossil fuels. Electricity makes up about 70 percent of the "electricity, gas, and sanitary services" industry aggregate in the NIPA, fossil-fuel steam accounts for almost three-quarters of electricity generation (the rest is mainly hydro and nuclear), and employees involved in generation make up about one-third of all employees on the payrolls of electric utilities.

Despite the relatively small fraction of total utility employment covered, the industry segment analyzed in this paper has experienced a slowdown in productivity growth very similar to that of the utility industry aggregate, as shown in Table 3. Here growth rates are computed over intervals between three-year averages of levels to smooth year-to-year variation in our sample of plants. Productivity growth in our sample of generating plants decelerates somewhat faster than the BLS index for the electric utility industry through 1978-80 but was almost identical to the BLS index in the last interval through 1985-87.

\section{Limitations}

While the electric generating industry is appealing as a subject for study, our regressions cover an extremely small fraction of U.S. employment and bear on only a small fraction of the total U.S. productivity growth puzzle. A second qualification is that the electric utility industry has entered a relatively "mature" phase of the industry growth cycle, and thus it may not be surprising that its productivity growth would decline over time. 
Productivity in Electricity Generation, Page 5

However, as we shall see the problems of the industry go far beyond those that can be attributed to maturity alone. A third qualification is that our data set, while it bas the great advantage that the majority of generating plants can be identified by vintage and observed over a long period of time, lacks particular explanatory variables that have become important during the productivity slowdown period, especially measures of technical characteristics like pressure, temperature, and the presence of scrubbers and cooling stacks. Other data sets, e.g., that of Joskow and Rose (1985), are complementary, having the advantage of including many of the technology variables needed to study the effects of environmental regulation, but lacking the advantage in our data set of the ability to observe a given establishment over a long period of time.

\section{TECHNOLOGY AND ITS IMPLICATIONS FOR RESEARCH}

\section{Characteristics of the Technology}

Although electric utilities are monopolists in the local markets they serve, the aggregate number of these individual monopolies is substantial, in contrast to the very small number of major producers of generating equipment. Thus utilities can accurately be described as price takers in the market for new equipment, and they also are "quality takers" in the sense that their choice set is constrained by whatever price-quality combinations are offered by equipment manufactures on the market at any given time. Research and development expenditures have taken place largely in the manufacturing sector, not in the 


\section{Productivity In Electricity Generation, Page 6}

utility industry. ${ }^{2}$

The production process involves the transformation of the internal energy in a fuel source into electrical energy. A power generation "unit" operates independently of any other units at a given plant location and consists of a boiler to burn the fuel and to generate and expand the steam, and a turbo-generator which converts high-pressure steam into electric energy through the rotary motion of a turbine shaft. A condensor converts the steam into water to complete the cycle. The entire unit is called a "boiler-turbo-generator", or BTG unit. A central measure of the efficiency of this transformation process is the "heat rate" (HR) of the cycle, the ratio of input in British thermal units (Btu) to one kilowatt-hour (KWH):

$$
H R=\frac{B T U \text { input }}{K W H \text { output }}
$$

Thus the higher the heat rate, the more fuel is being consumed in the production of a given amount of electricity, and the less efficient is the generation process. The heat rate moves inversely to a companion ratio called "thermal efficiency."

2 This verdict is qualified by Hirsch $(1989$, p. 71$)$, who argues that "to explain progress in electric power technology simply as a result of research and development performed by manufacturers would be one-sided and technology simpty as a result of research and development performed by maniste. The other side of technical advance is achieved by utility management, 67 percent of which in 1964 consisted of trained engineers. Managers in particular companies perceived themselves as competing for the role of technological leadership and constantly pressed equipment manufacturers to achieve technical advances, taking the risk that unproved technology would be successful. However, this role of management is not counted as research and development (R\&D) by normal accounting methods, and Hirsch bimself reports that utility-funded $R \& D$ in 1970 amounted to ouly 0.23 percent of gross revenues. 
Productlvity in Eiectricity Generation, Page 7

\section{Technology and the Sources of Economies of Scale}

Until the late 1960 s technical change in the design of BTG units was aimed primarily at increasing the size of generators and boilers, and at improving the thermal efficiency of the generating cycle by increasing the temperature to which the steam is heated, increasing the pressure of the steam entering the turbine, and reducing the heat which is transferred out of the cycle in the condenser. The technical design frontier was limited by the ability of boilers to withstand high temperatures and pressures, and the frontier was pushed out by incremental advances, particularly in metallurgy involving the development of high temperature steel alloys. Most of the shift to higher temperatures and to reheat cycles was completed during the 1948-57 decade, with little further change thereafter, whereas the increase in pressure rating continued until the late $1960 \mathrm{~s}$.

The average scale of BTG units also increased, with 58 percent of new units rated below 50 megawatts in 1948, and 60 percent above 500 megawatts in 1987. The increase in scale proceeded steadily through the mid-1970s and then ceased. Increased scale was interdependent with improved thermal efficiency, since many of the efficiency improvements required greater capital expenditures, the expense of which could be partially offset by increased scale. ${ }^{3}$ Cowing (1970) has dubbed this interaction between increasing scale and

3. Engineers use a "six-tenths" rule for approximating the additional cost of a capacity increase, i.e., a one percent increase in capacity increases capital cost by 0.6 percent, reflecting the geometrical fact that a one percent increase in the volume of a sphere increases its surface area by about 0.6 percent (Moore, 1959). 
technical improvements "scale augmenting technical change."4

The end of the era of increasing size helps to explain the productivity slowdown, and so it is important to determine whether the sources of the previous growth in scale had primarily been technological advance or the increasing size of the market. The technological hypothesis emphasizes the incremental advance of technology toward a technical ceiling reached in the late 1960 s, at the beginning of the slowdown period. In contrast the market hypothesis stresses the role of higher energy prices in the 1970 s in reducing the growth in demand for electricity, and predicts that further advances in scale should resume in response to the post-1983 decline in the real price of electricity.

One way to distinguish the two hypotheses is to ask why generator units were so small in the early part of the postwar period. Either manufacturers did not have the technical competence to produce larger units at reasonable cost, or markets were too small to support the purchase of larger units. One indirect piece of evidence that supports the technological explanation is that the average number of units installed per newly constructed plant during the $1947-50$ period was 2.0 , and six plants in our data set were built with three or four units during that interval. If larger pieces of equipment had been available at a lower cost per unit of capacity, they would have been purchased in place of two or more of the smaller units.

Numerous commentaries attribute the gradual increase in scale to a technological

\footnotetext{
4. As Wills illustrates $(1978$, p. 500$)$, there is little further improvement in thermal efficiency as unit sizes increase beyond 250 megawatts. Indeed, after increasing from 3 percent in 1880 to 22 percent in 1947, thermal efficiency leveled off at about 33 percent in the late 1950s and showed no change after than (Hirsch, 1989, Figure 1, p. 4).
} 


\section{Productlvity In Electrlcity Generation, Page 9}

frontier that advanced incrementally. For instance, an engineering study in the early postwar period carried out on units in the range of 50-100 KW stated: "we have every confidence that continued progress in metallurgy and design skill will make units larger than those now in operation economically feasible" (Kirchmayer et. al, 1955, p. 609). One of the conference discussants of the same study stated that "size must not nun ahead of our proved progress in metallurgy. From recent evidence it seems that size has now outrun progress" (p. 613). Hirsch emphasizes metallurgy, and attributes advances in size, pressure, and temperature in the early postwar years to "advances in metallurgical knowledge gained during the war and used in aircraft and artillery ... newly developed 'super alloy' steels that resisted metal fatigue and cracking, for example, allowed engineers to design larger components for more power output" (1989, p. 89-90). Thus the engineering literature appears to support the technological hypothesis over the market hypothesis as the primary source of scale economies achieved prior to 1970.

\section{Technology "Hits the Wall"}

Until World War II the traditional approach in achieving improvements in scale and efficiency had been the "design-by-experience" approach in which each step to a new technological plateau was followed by a period of debugging before the next advance occurred. In the postwar period, spurred by the rapidly growing demand for electricity, equipment manufacturers shifted to a more aggressive philosophy called "design-byextrapolation" in which the next advance was planned before operating experience had 


\section{Productivity In Electricity Generation, Page 10}

occurred with the previous step..$^{5}$ Much of the pressure for this new approach came from the demand for new equipment by utility management who were struggling to keep up with the demand created by a falling real price of electricity and by their own advertising designed to stimulate the use of electricity.

The first technological barrier to be reached was an effective upper limit to thermal efficiency, which had a natural theoretical limit of about 48 percent. Although a few bestpractice plants reached 40 percent, the steeply rising marginal cost of improving efficiency through the use of exotic and expensive steels prevented further progress. Further, experience revealed that the $100^{\circ}$ increase in temperature from the typical unit of the 1950 s to the 1960 s increased corrosive activity fiftyfold, led to the discovery that "we suddenly are susceptible to new diseases like stress corrosion cracking." Increased corrosion, in turn, required increased downtime for maintenance, and this in turn contributed to lower utilization rates on new units.

The arrival of the effective plateau in thermal efficiency in the late 1950 s increased the emphasis on scaling-up of boilers and generators, but by the end of the 1960 s this had also begun to create unanticipated problems. The scale frontier was reached when utilities discovered that downtime was as much as five times greater for units larger than $600 \mathrm{MW}$

5. Where no citations are given, specific details in this section are obtained from Hirseh (1989), Chapters 7-8.

6. Interview with a plant manager, quoted by Hirsch (1989, p. 93). 
than for units in the $100 \mathrm{MW}$ range. ${ }^{7}$ Part of this was directly a function of size, since the time required for units to cool down and heat up is directly related to the mass of the unit, and part related to the greater complexity of the larger units. Further, metallurgical problems cropped up in the huge turbine blades on large units, related to the laws of physics that dictated huge centrifugal forces, as much as 33 tons of force on a 7-pound blade.

The last component of the new technological era involved not just hitting a technological wall but rather amounted to a full-fledged retreat. Design-by-extrapolation led to the development in the late 1950 s and early 1960 s of the "supercritical" boiler (achieving a pressure above 3200 p.s.i.). However, after reaching a 63 percent share in new installations during 1970-74, the share fell to 6 percent in 1981-82 (Joskow-Rose, 1985, Table 1, p. 4). The backing off from supercritical technology resulted mainly from unanticipated maintenance problems, documented in the interviews at the end of this paper. ${ }^{8}$

The arrival of a technological frontier interacted with the pitfalls of the design-byextrapolation approach, which downgraded the importance of waiting for experience to accumulate with new larger units. ${ }^{9}$ Yet as time went on many problems developed that could have been alleviated with a more cautious approach, e.g., stability problems with

7. Joskow-Rose $(1985$, p. 23$)$ report that average equipment availability over the $1969-80$ period ranged from 82.8 percent for units of $100 \mathrm{MW}$ to only 62.6 percent for units of $900 \mathrm{MW}$.

8. The interviews contained in an early draft of this paper are cited as an explanation of the abandonment of supercritical units by Firsch (1989, pp. 97-9) and Joskow-Rose (1985, p. 23). Note that the Joskow-Rose evidence suggests that the availability penalty of supercritical units of given size is less than the penalty of increasing the size of subcritical units from 500 to $900 \mathrm{MW}$.

9. Hirsch (pp. 122-5) provides specific citations of overoptimistic predictions made in the 1950s and 1960s of continued steady advances in temperature, pressure, and size. 
turbines, twisted and cracked turbine blades, and ash buildup in furnaces. Because of large costs in downtime, added maintenance, and retrofitting of units with flawed designs, the initial cost of equipment appears significantly to understate the "true" cost of equipment delivered in the 1960 s. In more recent years manufacturers have learned from their design failures in 1960s-vintage equipment how to avoid design flaws and improve reliability, and failure rates for 1980 s vintage equipment have declined radically. ${ }^{10}$

A timing argument exempts environmental regulation from any appreciable blame in this technological history. Unanticipated problems developed in a major way with equipment manufactured in the early 1960 s, yet the response of utilities to environmental regulation is usually dated from the Clean Air Act Amendments of 1970 (Gollop-Roberts, 1983, p. 654). Yet as the 1970 s evolved, environmental regulation played a growing role in the slowdown in labor productivity growth and decline in thermal efficiency experienced by utilities, as regulations induced a shift away from soft coal, required major capital expenditures for scrubbers and other devices, and substantially raised the requirement for maintenance employees. Thus productivity growth was impeded after the early 1970 s by both the technological plateau and by environmental regulation, introducing a serious identification problem for any study attempting to explain the productivity growth slowdown.

10. The "forced-outage" rate after the first year of service for Westinghouse equipment dropped from 9 percent for equipment shipped in 1965-69 to 2 percent in 1975-80 to 0.5 percent in 1980-84. 
Productivity in Electrlclty Generation, Page 13

\section{Technological History and Its Implications for Econometric Research}

Previous research on the production process for electricity generation (Cowing-Smith, 1978; Wills, 1978) reached a consensus that the usual economic approach to production, based on the notion of homogeneous, divisible, and highly substitutable factor inputs, does not apply for this industry. Instead, the dominant feature of the production process is heterogeneous capital that incorporates the most efficient technology available at the date of its construction but, once builh, embodies fixed technical characteristics that impose very tight constraints on the feasible set of input-output combinations. The firm's choices are decomposed between "ex ante" investment decisions and "ex post" operating decisions, the latter involving the choice of variable inputs needed to produce desired output with existing equipment.

This two-stage view of the production process leads Barzel (1964), Wills (1978), and others to a two-step econometric procedure. The available opportunities that constrain the firm's investment decision are characterized in a hedonic price function that relates the price of equipment to its attributes. Then the operating decision is described in a regression of fuel, employment, or both, on the main attributes of each installed set of equipment. Wills concludes, in common with other studies dating back to Komiya (1962), that "substitution opportunities at the plant level between equipment, fuel, and labor are poor."

In light of the availability of recent research on the first-step hedonic regression for equipment prices, this paper concentrates on the second step, the regression equations 


\section{Productivity in Electricity Generation, Page 14}

explaining the usage of labor and fuel inputs for the installed stock of equipment. ${ }^{\text {I }}$ Such a study seems justified in view of the passage of time since the last round of studies by Cowing (1970, 1974), Wills (1978), and Bushe (1981). ${ }^{12}$ Another justification is that new questions have been raised by the productivity slowdown and by environmental regulation. Finally, most of the more recent studies have been based on firm rather than the establishment data used here and have been more concerned with measuring economies of scale than interpreting the productivity slowdown. ${ }^{13}$

\section{ECONOMETRIC SPECIFICATION AND DATA}

\section{The Employment Equation}

This section of the paper specifies a regression equation in which plant employment is explained by output and by various embodied characteristics of installed BTG units. This corresponds to the "ex post" or "operating" decision that, according to the consensus of previous research, is constrained by previous "ex ante" or "investment" decisions. Labor

11. See especially Joskow-Rose (1985) and Gordon (1990), which estimate equipment price indexes that decrease rapidly relative to the corresponding NIPA indexes through the late 1960s and rise much faster thereafter.

12. The earlier studies are surveyed by Cowing and Smith (1978).

13. Among these studies are Atkinson and Halvorsen (1984), Gollop and Roberts (1981, 1983), Cowing, Small and Stevenson (1981), and Christensen and Greene (1976). The advantages of plant over firm data are discussed by Cowing and Smith (1978), pp. 175-7, with reference to the papers by Nerlove (1963) and Christensen-Greene (1976). A dissenting opinion is offered by Gollop-Roberts (1981, p. 120), who argue that "producers make input decisions on the basis of technical and market conditions facing the complete system, not isolated plants." However, when plant data are available, there is no reason to make this choice ex ante, as aggregation issues can be studied explicitly by estimating firm and establishment effects, as in Table 12 below. 
Productlvity in Electricity Generation, Page 15

requirements and fuel use are taken to be endogenous choice variables, and equipment characteristics and output are the exogenous explanatory variables. Plant capacity, fuel type, and location are assumed to be predetermined by previous investment decisions, and output (or utilization), is assumed to be set by an exogenously determined demand for electricity at preset prices.

Because causation goes from output to inputs, and because there are two input equations, it is inappropriate to take the estimated coefficients from a single input equation, e.g., labor, and attempt to invert them to retrieve the underlying production function. We begin with the employment equation, relate it to previous research, and then subsequently adopt a parallel specification for the fuel input equation. The basic employment regression is estimated below for plant data in the following form:

$$
\begin{aligned}
\ln L= & \alpha_{0}+\alpha_{1} \ln C+\alpha_{2} \ln \left(\frac{Q}{C}\right)_{10}+\alpha_{3} \ln \varepsilon_{g R} \\
& +\alpha_{4} N+\alpha_{3} V+\alpha_{6} T+\sum_{i=1}^{0} \beta_{i} D_{i}+\varepsilon_{L},
\end{aligned}
$$

where $L$ is employment, $C$ is capacity, $Q$ is output, $\varepsilon_{H R}$ is the "heat rate residual" discussed below, $N$ is the number of units, $V$ is vintage, $T$ is the year of each observation, the $D_{i}$ are ten dummy variables for type of fuel, type of construction, and location, and $\varepsilon_{\mathrm{L}}$ is the error term. It is useful to compare (2) with other specifications of the employment equation, e.g., those of Wills (1978, p. 508): 


$$
\frac{L}{C}=\alpha_{0} \frac{1}{C}+\left(\alpha_{1}+\sum_{i=1}^{2} \beta_{i} D_{i}+\sum_{j=1}^{8} \eta_{j} \bar{T}_{j}\right) \frac{C}{C}+\alpha_{2} \frac{C^{2}}{C}+\varepsilon_{L C},
$$

and of Bushe (1981, p. 194):

$$
\ln L=\alpha_{0}+\alpha_{1} \ln C+\alpha_{2} \ln \left(\frac{Q}{C}\right)+\alpha_{4} N+\beta_{1} D+\varepsilon_{2}
$$

The additional symbol in the Wills equation is $\bar{T}_{j}$, which stands for a set of eight overlapping dummy variables for year of observation, in contrast to the linear time trend $(T)$ imposed in (2). ${ }^{14}$ The Bushe equation omits vintage effects and instead uses design data to divide up the total sample into seven technically homogeneous cells, and the coefficients in equation (4) are separately for each cell. The log-linear functional form of our specification (2) is shared with (4). In contrast, in (3) Wills begins with a linear form but allows for interaction effects and normalizes by capacity. Bushe also implicitly normalizes by capacity, since the average capacity within his seven separate cells differs by several orders of magnitude.

A basic difference between the three specifications is the allowance for both time and vintage effects in (2), only vintage effects in (3) and only "cell" effects in (4). The vintage variable is included in (2) but not in (3), because the latter includes observations only for newly installed plants, whereas the former includes observations for each year of operation. The Bushe approach in (4) appears to be inconsistent, in that data for multiple years of

14. The two dummy variables in the Wills equation are for presence of coal burning and of more than one unit, and in the Bushe equation the single dummy variable represents the presence of coal burning. 
operation are included for each plant but no vintage variable is introduced. ${ }^{15}$

The larger number of dummy variables included in (2) reflects the much larger sample size in our study. Our sample consists of 6674 observations after editing, in contrast to 163 for Wills and cell sample sizes ranging from 25 to 162 for Bushe. Our larger sample size stems both from the inclusion of each plant for every year of operation (starting from the first complete year), and also the addition of 18 extra years of data beyond that available to Bushe and Wills.

Because our point of departure is the productivity slowdown, the estimates below of (2) allow the vintage $\left(\alpha_{5}\right)$ and time $\left(\alpha_{6}\right)$ coefficients to shift after 1968. We attempt to identify the sources of these shifts by allowing for interaction effects and by isolating observations that are consistent "outliers." Another difference among the specifications is apparent in Wills' omission of an output or utilization variable, in contrast to its inclusion in equations (2) and (4).

\section{The Fuel Input Equation and the "Heat Rate Residual"}

The conventional economic theory of production based on homogeneous and highly substitutable inputs might lead to the expectation of a negative coefficient on the heat rate (energy use divided by output) stemming from substitution between energy and labor. In contrast our basic approach holds that there are few ex post substitution opportunities

15. Bushe edits his sample to include observations beginning in the second full year of operation and extending until the end of the sample or two years prior to installation of a new unit. We begin in the first full year of operation and apply a different editing criterion described in the Appendix. 
involving energy use. Instead, we view the coefficient on the heat rate in our employment regressions as a proxy for unmeasured design characteristics of plants of a given capacity and vintage. Our treatment of the heat rate variable as an indicator of plant efficiency is consistent with the approach of Schmalensee and Joskow (1985, p. 1), who explicitly list heat rate as one of two "indices of quality," the other being the plant's availability factor.

To embody the idea that the heat rate effect represents unmeasured design characteristics, in the present paper the employment equations include not the heat rate itself, but rather the residual from the fuel input equation, $\varepsilon_{\mathrm{HR}}$, which is specified:

$$
\begin{aligned}
\ln H R & =\alpha_{0}+\alpha_{1} \ln C+\alpha_{2} \ln \left(\frac{Q}{C}\right)+\alpha_{3} \ln \left(\frac{P_{g}}{P_{L}}\right) \\
& +\alpha_{4} N+\alpha_{5} V+\alpha_{6} T+\sum_{i=1}^{10} \beta_{l} D_{l}+\varepsilon_{B R} .
\end{aligned}
$$

The specification of the fuel input equation is identical to that of the labor input equation (2), except that the heat rate term in (2) is replaced by the relative price of fuel $\left(P_{F} / P_{L}\right)$. After (5) is estimated, the residual for each observation is included as an explanatory variable in (2).

\section{Data and Estimation Issues}

The data file includes all plants listed in the publication Steam-Electric Power Construction Cost and Annual Production Expenses for the period 1948-87. In total 401 individual plants are represented, of which 68 were constructed prior to 1948, 113 during 1948-57, 75 during 1958-67, 97 during 1968-77, and 48 during 1978-86. Since each plant is 


\section{Productivity In Electrlcity Generation, Page 19}

observed in each successive year starting with the first year after its commencement of operations, the sample is quite large, consisting of 7701 observations prior to editing. Editing pruned the sample down to 6656 observations, as described in the Appendix.

Several features of the data need to be considered when interpreting the econometric results below. The greatest problems are posed by the presence of technically beterogeneous units in some multi-unit plants, and by varying technical specifications in new plants of a given vintage. Spurious errors caused by the first of these can be minimized either by editing the sample or by including dummy variables. The second cannot be escaped but should cause no bias in coefficients if the distribution of technical features across plants of a given vintage tends to remain constant over successive vintages. A final data problem involves possible measurement errors in the data on plant employees. ${ }^{16}$

Table 4 exhibits for selected intervals, separately for new plants and all plants, the annual average number of plants, and their average capacity $(C)$, utilization rate $(Q / C)$, and output per employee $(Q / L)$. The new plants have a smaller capacity than the average for all plants in several of the early intervals. This apparent discrepancy can be explained by a greater number of small-sized units in existing plants (average units per plant decreased steadily from 11.0 in pre-1948 plants to 1.5 in plants of the 1986 vintage). ${ }^{17}$ Productivity in new plants actually declined by two-thirds between $1966-68$ and 1986-87, while productivity

16. Bushe complains that the labor data are "imprecise" and "misleading" and cites instances of firms that allocate all maintenance labor to one plant. We return to this issue in discussing our interviews with managers of outlier plants.

17. There were no new plants built in 1987 , a fact confirmed by Hirsch (1989), p. 165. 
on all plants increased by 9 percent. The two final columns exbibit the striking finding that the utilization rate for new plants was higher than for all plants prior to 1968 , while the reverse was true beginning in 1969-71.

\section{ESTIMATED FUEL AND LABOR INPUT EQUATIONS}

\section{The Fuel Input Equations}

The estimated coefficients for the fuel input equation (5) are presented in Table 5, where the three columns report results for all plants in the edited sample, and for the subset of coal-using and noncoal-using plants. ${ }^{18}$ The significance of coefficients is indicated by asterisks, and every coefficient in the table is significant at the one percent level, with three exceptions.

The negative coefficient on capacity implies that the well-documented economies of scale in equipment cost and labor use extend to fuel use as well. The negative coefficient on utilization could indicate both that plants which experience a lot of downtime are also inefficient users of fuel, and that fuel is wasted when plants are shut down for maintenance and then started up again. The relative price term has the expected negative sign and is much larger for coal than noncoal plants. As would be expected, plants which generate a

18. The vintage and time trend shifts are defined in exactly the same way. The vintage trend is centered on 1968, that is, equals -20 in 1948,0 in 1968 , and +19 in 1987. The vintage trend shift variable equals zero in all years through 1968, and then equals the trend running from +1 in 1969 to +19 in 1987 . The "base" for the fuel-use dummy variable refers to plants which use both oil and gas. 


\section{Productivity In Electricity Generation, Page 21}

given output with several small units use more fuel than plants with fewer and larger units. ${ }^{19}$

Both the vintage trend and time trend coefficients have a V-shaped pattern, with a negative overall trend more than offset by a positive post-1968 trend. The trends imply for all plants in column (1), for instance, that a 1948-vintage plant of given size used 2 percent more fuel per unit of output than a 1968 plant, and that a 1987-vintage plant used 9.5 percent more fuel. All of the deterioration after 1968 can be attributed to coal plants, since the two vintage terms for noncoal-using plants are of equal and opposite sign, implying flat fuel use after 1968. The time trend coefficients imply the same V-shaped pattern for plants of a given vintage observed in successive years and are consistent, for instance, with the effect of environmental regulations in causing a shift from high-sulfur to low-sulfur coal and oil requiring more BTUs to generate a unit of output. ${ }^{20}$ The results indicate that the experience of coal and noncoal plants differs; the $F(19,6819)$ ratio of 29.1 far exceeds the one percent critical value of 1.87 , indicating that the data for the two fuel types cannot be pooled as in column (1).

An interesting interaction among the coefficients becomes evident when the equations in Table 5 are reestimated with the relative price variable omitted. This causes

19. Building fewer and larger units per plant economizes on capital cost and labor as well as fuel. See Hirscb (1989, p. 43), who also notes that prior to the 1930s as many as eight boilers were necessary per turbinegenerator, but that by the 1930 s firms had learned how to economize pith "unit-type" construction, that is, one boiler per generator.

20. Gollop and Roberts (1985) provide data on the cost of pollution control equipment and required reductions in emissions, but not on the fuel-using effect of shifting to low-sulfur fuel. 


\section{Productivity in Electricity Generation, Page 22}

the time trend and trend shift coefficients to drop by roughly half. Thus, with the relative price omitted, about half of the pre-1968 improvement in fuel use for plants of a given vintage, and about half of the post-1968 deterioration, is offset by the effect of a falling relative price in stimulating fuel use before the late 1960 s and in encouraging fuel conservation after the early 1970 s.

\section{The Basic Employment Equation}

The first column of Table 6 reports the estimated coefficients for the basic employment specification (equation 2 above) for the edited sample of 6674 observations. ${ }^{21}$ The elasticity of employment to capacity changes is 0.54 , confirming the substantial economies to scale found in previous studies. ${ }^{22}$ The elasticity of employment to utilization

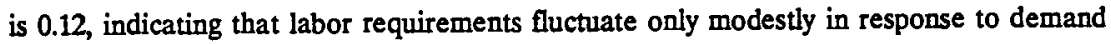
changes, and thus that labor productivity is highly sensitive to changes in utilization. Taken by itself, this coefficient suggests that labor productivity should have declined in the 1970 s in response to decreasing average utilization (shown in Table 4).

The coefficient on the heat rate residual is positive, suggesting that plants having relatively high energy requirements also have relatively high labor requirements. This coefficient can be interpreted as a proxy for unmeasured design differences among plants

21. There are fewer observations here than in Table 5 , because there are some observations which are missing data on employment but not the heat rate.

22. Joskow and Schmalensee (1983, pp. 48-54) provide a relatively recent survey. 


\section{Productivity In Electricity Generation, Page 23}

of a given vintage and capacity. ${ }^{23}$ A plant having a relatively large number of small units requires, understandably, more labor than another plant having the same capacity but a relatively small number of larger units.

In lines 5 and 6 we find that the labor productivity slowdown has occurred across both vintage and date of observation. The vintage trend coefficient is -0.015 for all years, whereas the vintage shift variable has a coefficient of +0.032 , indicating a net deterioration of productivity growth during 1968-87 at a rate of 1.7 percentage points per year on successive newer vintages. The productivity of older plants deteriorated as well after 1968. The coefficient for the trend on date of observation is -0.027 , and that of the $1968-87$ shift variable is 0.047 , indicating that after 1968 the productivity of existing plants of all vintages deteriorated at a rate of 2.0 percentage points per year. Overall, successive vintages improved in productivity by 30 percent between 1948 and 1967, after which productivity declined by 32 percent between 1967 and 1987. Plants of all vintages observed in 1967 had a productivity performance 54 percent better than plants observed in 1948, but afterward there was a decline in productivity amounting to 38 percent by 1987 . These estimates hold constant the influence of capacity and utilization; hence in the early years these trends understate the true effect of increasing vintage in contributing to productivity growth, since increased capacity over successive vintages raised productivity until 1968, while after 1968 size levelled off but utilization fell, thus causing the time trend coefficients to understate the

23. The estimation of the heat rate residual implies that it is independent of the other explanatory variables in the equation, and hence it is not surprising that there is virtually no change in the other coefficients in the employment equation if the heat rate residual is omitted. 


\section{Productivity in Electricity Generation, Page 24}

true deterioration of productivity.

The final set of coefficients refers to dummy variables for fuel use. Coal use (either by itself or together with other fuels) raises employment requirements by 19 percent compared to oil-only and 21 percent compared to gas-only plants. ${ }^{24}$

The other columns in Table 6 exhibit the results for the subsample of coal-using and noncoal-using plants. The major differences are that the utilization effect is smaller for both fuel groups when the sample is disaggregated; the heat rate effect is much higher for noncoal plants, while the post-1968 deterioration in productivity measured by the vintage trend shift applies only to coal plants, since noncoal plants show an acceleration in productivity improvement over successive vintages. The V-shaped time trend coefficients apply to both fuel groups, but the slope of the "V" is steeper for coal plants. The $F(18,6636)$ ratio of 71.9 , compared to a one percent critical value of 1.87 , provides strong evidence that the observations for the coal and non-coal plants are not generated from the same relationship.

\section{Variations on the Basic Employment Equations}

1. Year Triplets. The first variant is to replace the simple trend and trend shift terms with separate vintage and time coefficients for successive intervals of three years each ("year triplets"), 1949-51, 1952-54, etc. The results are plotted in Figure 1, where the top

24. This compares closely with the average of 22 percent for the coal use dummy across the seven cells in Bushe's study (1981, p. 192). The linear specification of Wills' employment equation precludes direct comparisons with his coefficients. 
frame displays the percentage deviation of each vintage coefficient from the 1967-69 coefficient, and the bottom frame shows the same percentage deviation for the time coefficients. The time coefficients in the bottom frame display the same "V-shaped" pattern as the more parsimonious specification in Table 6, and repeat our previous finding that the " $\mathrm{V}$ " has a steeper slope for coal than for noncoal plants. Also, we can see here that the pattern for the noncoal plants is better described as a "U" than a "V", with a long flat portion between 1965 and 1980.

However, the vintage coefficients in the top frame of Figure 1 do not trace out a simple "V-shaped" pattern and indicate that the parsimonious specification of Table 6 is oversimplified. The $F(24,4140)$ ratio of 3.29 for coal plants and $F(22,2450)$ ratio of 8.64 for noncoal plants indicates that the employment equation with separate coefficients for the year-triplets fits significantly better than the specification in Table 6 that imposes two linear trends centered on 1968. However, since the other coefficients in the equations appear to be almost identical whether the Table 6 or year-triplet specification is used, we will explore the other variants in this section with the Table 6 specification.

2. Average Vintage. The next variant is to move to a more accurate measure of plant vintage. The results in Table 6 are based on the vintage listed in the original data source, which is the date when the plant was first constructed. However, this does not take account of the fact that many plants install additional units at a later date. A more accurate vintage measure takes the average vintage of all units in the plant installed as of a given year of observation. The disadvantage of this approach is that it requires throwing away all 


\section{Productivity in Electricity Generation, Page 26}

observations on plants of pre-1948 vintage, since we have no information on the addition of new units before 1948. There are several interesting changes in the coefficients in Table 7 as compared with Table 6. The utilization coefficient for noncoal plants becomes insignificant, as does the beat rate residual coefficient for coal plants. The "V" of the vintage trends becomes steeper for both fuel types, while the "V" of the time trends becomes flatter for both fuel types.

3. Sample Split. All employment equations thus far force the coefficients other than the vintage and time trends to be identical over the entire 1948-87 sample period. Table 8 examines the validity of this constraint by estimating separate equations for 1948-67 and 1968-87, while retaining the measure of average vintage introduced in the preceding section. There are numerous changes in coefficients, indicating a change in structure over the two halves of the postwar period. The capacity coefficients rise in the second balf for both fuel types. The utilization coefficient for coal now has the wrong sign in the first balf and is insignificant for noncoal in both halves. The heat rate residual coefficient is significant only in the first balf for both fuel types, indicating perhaps more beterogeneity in design in the pre-1968 period. However, there is no important change in the vintage or time trend coefficients. Both imply the usual "V-shaped" pattern for both the vintage and time effects. The $F(14,3004)$ ratio of 13.5 for coal and the $F(14,1960)$ ratio of 5.1 for noncoal indicate that the equations for the two halves of the postwar period cannot be pooled.

4. Interaction Effects. The shift in structure over time suggested in Table 8 can be parameterized in a single equation by allowing for interaction effects among fuel type, heat 
rate, utilization rate, and vintage, that may partially explain some of the behavior of individual coefficients in Tables 6 and 7. In Table 9 heat rates and utilization rates are displayed for new plants built at selected vintage intervals and for three fuel types. For coal-using and oil-only plants, the relationship between vintage and heat rate traces out a backward "J." This reversal still leaves the heat rate in 1983-86 lower (better) than in 194852 , in contrast to the implication of the vintage trend for coal plants in Table 5 (which shows that the reversal more than cancelled the 1948-68 improvement). We can reconcile this conflict when we recognize the role of the capacity effect in the regressions, which explains part of the 1948-68 improvement in heat rate by increased scale rather than by the vintage trend.

Exploration of every possible interaction effect for each of the three equations in Table 6 is infeasible. Instead, the basic equation for coal-using plants with average vintages (column 2 in Table 7) is presented in Table 10 with the addition of various interaction effects. The previous discussion suggests that there may be important interaction effects between vintage and vintage-shift, on the one hand, and capacity, utilization, and heat rate, on the other hand. All six of these possible interaction effects are included in column (2) of Table 10, and three are statistically significant-the log of capacity times the vintage variable and vintage shift variables, and the heat rate residual times the vintage shift variable. Column (3) estimates the same equation with only the five significant interaction variables included from column (2). The first two interaction terms (lines $5 \mathrm{c}$ and $5 \mathrm{~d}$ ) indicate that the "V-shaped" pattern of the vintage shift is steeper for small than for large 
plants. $^{25}$ They also imply that the scale coefficient is hump-shaped, rising from 0.54 in 1948 to 0.71 in 1968 , and then falling to 0.49 in 1987 . The effect of increasing scale on productivity is measured by unity minus this coefficient, and thus is V-shaped. The implication that the productivity benefits of increased scale were lowest in 1968 seems consistent with the maintenance problems of large plants built in the late 1960s, as discussed in section VII below. The third interaction effect indicates a more severe adverse vintage shift for plants that are energy inefficient.

We may also inquire which characteristics are correlated with an adverse "time shift," i.e., tendency to require more employees with increasing plant age after 1968 as compared to before 1968. The time shift interactions in column (4) indicate that this age deterioration effect was greatest for plants that were relatively large, heavily utilized, and energyinefficent. The utilization interaction can be described in a second way: the employee requirements imposed by an above-average utilization rate increased after 1968, possibly because environmental regulations raised the employee requirements of maintenance for high-utilization plants. Stated a third and perhaps more appealing way, the employee savings made possible by a low utilization rate were greater after 1968, perhaps because plant managers interpreted the low utilization rates as permanent rather than temporary as in the 1950 s and reduced their work forces accordingly. It is important to note that the interaction terms in column (4) cause the time shift variable to lose statistical significance.

25. The implied vintage and vintage shift coefficients for $200 \mathrm{MW}$ plants are -0.032 and +0.069 , and for 2000 MW plants are -0.012 and +0.019 . 
Productivity in Electricity Generation, Page 29

\section{Implications of the Coefficients for the Productivity Growth Slowdown}

The sources of the productivity slowdown in the industry can be decomposed for alternative equations and for alternative sets of years. Lines A and B compare the growth rates of actual and predicted output per employee over the sample of coal-using plants. The predicted value is based on actual output and the equation's prediction of employment based on the estimated coefficients of column (4) in Table 10, multiplied by the mean values of each independent variable for the year in question.

The seven lines of section $\mathrm{C}$ of the table decompose predicted productivity growth in each decade among the contributions of the independent variables in the equation. Each contribution is calculated by multiplying the appropriate coefficient times the change in the independent variable over the previous decade. This is done in straightforward fashion for the variables listed in lines $\mathrm{C}$ through $\mathrm{C}$, where output is treated as exogenous and every predicted change in employment creates a change in productivity of the opposite sign. The calculation of the effects of changing capacity and utilization require an extra step, since both output and employment are altered. Line 1a shows the direct effect of higher capacity on output, and line $1 \mathrm{~b}$ subtracts that effect times the estimated coefficient on capacity in the employment equation (0.623). Similarly, line $2 \mathrm{a}$ shows the direct effect of changing utilization on output growth, holding constant capacity, while line $2 \mathrm{~b}$ subtracts the (nearzero) coefficient on utilization in the employment equation. The interaction effects of vintage and time with capacity are grouped together on lines $1 \mathrm{c}$ and $1 \mathrm{~d}$ under capacity, and similarly the interaction effect of time with utilization is shown on line $2 c$, while the heat 


\section{Productivity in Electricity Generation, Page 30}

rate interactions with vintage and time are shown on lines $3 b$ and $3 c$.

The results in Table 11 can be combined in different ways to provide a summary of the causes of the productivity problems of the coal-using steam-electric plants. One useful technique is to divide the causes into three categories, (1) "exogenous" factors including higher fuel prices and macroeconomic business cycles that have caused changes in utilization, (2) "technical design" factors that influence the employment requirements of new equipment, including capacity, heat rate, units, and vintage, and (3) "operating" factors that cause changes in labor requirements on existing equipment represented in our equation by the time effect. As we shall see below, there is substantial interaction between (2) and (3), since extra labor hired on existing equipment may be required to repair problems resulting from design flaws. The following is the breakdown of the factors associated with the productivity slowdown:

Slowdown, 1958-68 to $1948-58 \quad 1958-68 \quad 1968-78 \quad 1978-87 \quad 1968-87$

$\begin{array}{lrrrrr}\text { Exogenous } & 3.35 & -0.45 & -1.90 & 1.43 & 0.13 \\ \text { Technical Design } & 6.36 & 5.54 & -2.55 & -2.26 & -7.95 \\ \text { Operating } & 1.10 & 1.10 & -0.10 & -0.10 & -1.20 \\ \text { Other + Residual Error } & -1.98 & -1.44 & \underline{2.67} & -0.58 & \underline{3.12} \\ & & & & & \\ \text { Equals: Actual Productivity Change } & 8.83 & 4.75 & -1.88 & -0.35 & -5.91\end{array}$

The first decade is somewhat unusual, as the "vintage averaging" procedure cuts out all pre1948 observations and leaves a small and atypical sample of plants in 1948, the first year of observation. Somewhat more instructive is the comparison between the second and the average of the third and fourth periods, i.e., between 1958-68 and 1968-87. The total 


\section{Productivity in Electricity Generation, Page 31}

productivity slowdown of 5.91 percentage points at an annual rate is overexplained by the design and operating factors, with virtually no role for the exogenous utilization factor.

\section{FIRM AND ESTABLISHMENT EFFECTS}

This section provides an evaluation of establishment and firm effects. We are interested in determining whether a specification error occurs when the employment equations omit variables with establishment structure, and whether there are firm effects beyond those associated with the regional, fuel, and construction-type dummy variables in the basic specification. The estimation of establishment and firm effects also allows us to deal with the possibility of simultaneity in the employment regressions. While the basic assumption that capacity and output are exogenous in the short run seems convincing, there may be cases where maintenance problems or other factors cause a plant to be taken temporarily out of operation, leading to a simultaneous reduction in employment and output. The exogenous demand would then be satisfied by other plants owned by the firm or by purchases of power from other firms, leading to negative correlation of residuals among plants of a given firm. Another type of "firm effect" would occur if firms operate with different managerial procedures that yield consistently good or poor productivity performance.

The basic specification examined above can be written as the following general linear model:

$$
y_{k}=\beta_{\alpha}+\sum_{k}^{x} \beta_{k} x_{i b}+\varepsilon_{i k}, \quad i=1, \ldots, N
$$


where $i$ indexes individual establishment observations observed at each time period $t$; there is a vector of $K$ explanatory variables $x_{i j i}$ explaining each observation $y_{i s}$ and the $\varepsilon_{i b}$ are a set of independent and identically distributed disturbances with zero expectation and a finite variance. ${ }^{26}$ The previously estimated employment and fuel use equations ( 2 and 5 ) share the feature of (6) that the $\beta_{k}$ coefficients are assumed to be identical for all establishments and time periods (except that we have allowed for a vintage shift effect); and that our equations include one or more time trends.

An initial question involves the possible existence of individual establishment effects. Employment in a given establishment might be higher or lower year after year than can be explained by the included $x_{i k t}$ variables, and such an effect could bias any of the estimated coefficients. An establishment effect exists if there is a determinant of establishment employment that has the same value for a given establishment in all time periods but whose value differs between establishments.

The analysis of establishment effects begins by taking the mean over time of the general linear specification in (6). This provides a structural relationship between the mean of the dependent variable over time for each establishment and the means of the right-hand variables over time for each establishment:

26. This exposition adapts for time-series purposes the approach devebped within the cross-section context by Pakes (1983). I am gratefil to Ariel Pakes for his help in developing this exposition. 


$$
\begin{aligned}
& \bar{y}_{i}=\beta_{\alpha}+\sum_{k}^{K} \beta_{k} \bar{x}_{i k}, \text { where } \\
& \bar{y}_{i}=\frac{\sum_{1} y_{t}}{T} ; \quad \bar{x}_{i k}=\frac{\sum_{i} x_{i k t}}{T}
\end{aligned}
$$

Then the explanation of individual establishment employment $\left(y_{i j}\right)$ is decomposed into establishment-mean effect and a time-specific effect for each plant. Subtracting (7) from (6), we obtain:

$$
y_{i k}-\bar{y}_{l}=\sum_{k}^{r} \beta_{k}\left(x_{i k t}-\bar{x}_{i k}\right)+\varepsilon_{i t} .
$$

The issue to be explored is the correlation of the individual establishment effects with the mean characteristics of each establishment averaged over time. We investigate the hypothesis that there are establishment effects that are correlated with establishment mean characteristics. The remaining variance of $\beta_{\alpha}$ is associated with an independent establishment error term $\eta_{i}$ :

$$
\beta_{\alpha}=\beta_{0}+\sum_{k}^{E} \phi_{k} \bar{x}_{i k}+\eta_{i} .
$$

The $\phi_{k}$ establishment effect parameters can be estimated directly, and an "establishment effect" is said to occur when the $\phi_{k}$ parameters are different from zero. Substituting (9) into (7), and adding the resulting expression to (8), we obtain a relationship among the 
underlying observations of the dependent variable $\left(y_{i t}\right)$ :

$$
y_{\dot{i k}}=\beta_{0}+\sum_{k}^{E} \phi_{k} \bar{x}_{i k}+\sum_{k}^{K} \beta_{k} x_{i k t}+\varepsilon_{i k}+\eta_{i} .
$$

The "establishment effect" $\left(\phi_{k}\right)$ parameters capture the correlation between average plant employment and the average values over time of the other right-hand variables, including capacity, utilization, heat rate, units, vintage, time, and the dummy variables for location, type of fuel, and type of construction. The $\beta_{k}$ parameters estimate the remaining response of employment to a unit change in a right-hand variable within a given time period, given the "establishment effect" parameters. Thus the $\phi_{k}$ parameters can be thought of as "permanent" effects of changes in the explanatory variables, and the $\beta_{k}$ parameters can be treated as "transitory" effects. ${ }^{27}$

By definition, since the vintage observation of a given plant is fixed over time, the vintage trend must be a between-establishment effect, while all the variance of the timetrend occurs over time and must then be a within-establishment effect. A plausible outcome for the other coefficients in (10) would be to find that the $\phi_{k}$ between-establishment parameters capture all of the influence on employment of capacity, heat rate, and the number of units, while the $\beta_{k}$ within-establishment parameters capture the influence from year to year of the utilization and time-trend variables. As is evident from columns (2) and

27. The specification written in (10) does not represent the only possible method of estimating the $\phi_{k}$ establishment parameters. Pakes (1983) suggests a two step procedure in which one estimates first (6) and then (8), obtaining the $\phi_{k}$ estimates as the difference in the $E_{k}$ estimates from the two stages. But the estimation of (10) directly is both simpler and yields a direct estimate of the standard errors of the $\phi_{k}$ parameters. 


\section{Productivity in Electricity Generation, Page 35}

(3) of Table 12, however, this sharp dichotomy turns out to be true only for the utilization variable. Capacity and heat rate have both between and within effects, while the coefficients on the number of units are insignificant. The within-establishment effects of capacity and heat rate suggest that additions and retirements of equiprnent are important causes of changes in employment over time for a given establishment.

\section{Allowing for Firm Effects}

The variance in employment can be decomposed into three components, that is, within-establishment-across-time, across-establishments-within-firms, and across firms. One possible type of firm effect might be cross-plant sharing of maintenance or management labor. This is essentially an errors-in-variable problem, in the sense that if employees at one plant are doing maintenance for one or more other plants, the level of capacity relevant for the explanation of employment is incorrectly measured.

We can rewrite the basic specification, altering (6) to let $j$ index firms, and $i$ index establishments within firms. Then (6) becomes:

$$
y_{i j k}=\beta_{0 j j}+\sum_{k}^{E} \beta_{k} x_{i j k}+\varepsilon_{i j k} .
$$

Now we define establishment means over time and firm means over establishments as

$$
\bar{y}_{t j}=\sum_{i} \frac{y_{i t}}{T} ; \bar{x}_{i z}=\sum_{i} \frac{x_{v t}}{T} ; \bar{y}_{j}=\sum_{i} \frac{\bar{y}_{i j}}{N_{j}} ; \bar{x}_{j k}=\sum_{i} \frac{\bar{x}_{i j}}{N_{j}}
$$

where $N_{j}$ is the number of establishments at firm $j$. Now the cross-firm relationship and 
within-firm-over-time relationship can be written as:

$$
\begin{aligned}
& \bar{y}_{j}=\beta_{0 j}+\sum_{k}^{K} \beta_{k} \bar{x}_{j k} \\
& \bar{y}_{i j}=\beta_{0 i j}+\sum_{k}^{K} \beta_{k} \bar{x}_{i j k} .
\end{aligned}
$$

We now define the establishment effect as in the above analysis,

$$
\beta_{0 i j}=\beta_{0 j}+\sum_{k}^{L} \phi_{k} \bar{x}_{i j}+\eta_{j j},
$$

and firm effects by analogy:

$$
\beta_{0 j}=\beta_{0}+\sum_{k} \theta_{k} \bar{x}_{j k}+\xi_{j}
$$

Substituting (14) and (15) into (11), we obtain an equation that can provide direct estimates of the establishment and firm effects.

$$
y_{i j k}=\beta_{0}+\sum_{k}^{K} \theta_{k} \bar{x}_{j k}+\sum_{k}^{K} \phi_{k} \bar{x}_{i k}+\sum_{k}^{K} \beta k x_{i j k}+\xi_{j}+\eta_{i j}+\varepsilon_{i j k} .
$$

The three right-hand columns in Table 12 exhibit the coefficient estimates for the three-way decomposition of within-establishment, between-establishment, and between-firm effects. The $\beta_{k}$ coefficients for the within-establishment effects in column (4) are very close to those in column (2). The between-establishment coefficients in column (5) are basically similar to those in column (3), although the capacity coefficient rises from zero to a 
marginally significant 0.071 , and the negative utilization effect becomes significant. This apparently perverse utilization effect means that a plant having a high average utilization rate has a relatively high level of plant productivity, and this correlation may be induced by reverse causation, since high-productivity plants are likely to be the "base load" plants that experience the highest utilization rates.

A broader evaluation of Table 12 yields a mixed verdict on the inclusion of the establishment and firm effects. On the one hand, both effects are clearly significant, as is obvious from the high estimated $t$ ratios. Also, a Chow test for the inclusion of the establishment effect in columns (3) and (4) yields a $F(4,2969)$ ratio of 7.8 , compared to a one percent critical value of 3.32. A test for the inclusion of the firm effect in addition to the establishment effect yields a $F(8,2965)$ ratio of 43.2 , compared to a one percent critical value of 2.5. On the other hand, the inclusion of the establishment and firm effects does not change any of our previous conclusions regarding the central vintage shift and time shift coefficients. For instance, the vintage shift coefficient in column (l) for the basic equation is 0.046 and is reduced only to 0.044 in the full equation in column (5).

\section{A SURVEY OF "OUTLIER" PLANTS}

Our decomposition of the productivity slowdown at the end of part $V$ provides a catalogue of factors which, while they help to explain the slowdown, themselves are in need of explanation. To report that productivity growth decelerated because capacity growth decelerated, the beat rate increased, and because there were "vintage shifts" and "time shifts" 
is not very helpful unless we can begin to understand why these adverse events occurred.

In this section we attempt to learn something about the industry's problems from those most closely involved, the plant managers themselves. The technique is simply to telephone the managers of plants with the largest positive and negative residual errors on average during the last five years of the sample period, in order to learn about their own explanation of the relatively high or low level of employment at their plants. These telephone calls are useful not just in isolating "special factors" that require unusually high levels of employment at some plants, but also in obtaining a set of explanations for the behavior of some of our explanatory variables, particularly capacity, utilization, and heat rate, and the roles of environmental legislation and the "depletion hypothesis" in contributing to that behavior.

\section{Characteristics of Outlier Plants}

The telephone interviews were carried out in two steps, once in 1982 for the first draft of this paper, and again in 1990 when the research was updated. In the early interviews outliers were chosen as those with the highest or lowest residuals (actual minus fitted) in the last five years of the sample period, then 1974-78. In the early interviews only positive outliers were telephoned, reflecting our interest in the disappointing productivity performance of the industry. This asymmetry was partly corrected in the second batch of interviews, where more negative than positive outliers were telephoned. ${ }^{28}$

28. The interviews were conducted October 11-18, 1982, and July 9-12, 1990. 
Summary data on the outlier plants are provided in Table 13 . The early group of plants displays systematic differences, in that the positive outliers are newer and larger than the negative outliers. In the early group eight of the 17 positive outliers had vintages of 1968 or newer, while none of the negative outliers were post-1968 in vintage (and seven of the 12 were vintage 1950 or earlier). The early group also appears to display a somewhat skewed distribution, in that the average log residual for positive outliers is much larger than for negative outliers. The later group of outliers displays more similarity between the positive and negative averages, with roughly the same average vintage and less skewness. ${ }^{29}$ Eight of the positive outliers and nine of the negative outliers are post-1968 in vintage. There is still a tendency, however, for the positive outlier plants to be larger than the negative outlier plants. ${ }^{30}$

The residuals used to choose the early group of outliers come from the original employment equation in Table 6, column (1), estimated for the period 1948-78. The later group come from the same equation, estimated for the period 1948-87, and the facts reported in the rest of this paragraph refer to the more recent results. The estimated coefficients in the regression for the complete sample period excluding the 30 outlier plants

29. There is substantial turnover in the group of positive outliers: of the 17 plants in the early group identified from data ending in 1978 , only fre appear in the list of positive outliers based on average residuals during 1983-87. Of the other 12 plants, six disappeared from the data set or changed their identity when small adjacent plants were consolidated; and the average residual for the remaining six in 1983-87 was only 0.12. None of the early group of negative outliers reappeared in the later group.

30. Why are positive outliers more likely to be large plants? One reason is that large plants are more likely to have supercritical boilers, a technology that (as we see below) led to unanticipated maintenance requirements that raised employment. Rose-Joskow (1990) bave studied the diffusion of innovation in the industry and conclude that larger firms were more likely to adopt supercritical units. 
differ little from those in the equivalent regression for the inclusive group. Obviously, the standard error declines as the outliers are excluded, from 0.373 to 0.348 ; the unexplained variance is reduced by 22 percent by the exclusion of 8 percent of the plants. The main coefficients of interest, the vintage and time effects and their 1968-78 shifts, change little. The absence of any important change in the 1968-87 year shift effect implies that the role of the outlier plants constructed before 1968 is to raise the residual error in all years, and not to contribute an unexplained increase in employment after 1968.

As indicated in Table 13, 24 plant managers were contacted, 12 in the early group and 12 in the late group. No individual refused to enter into a discussion. The only limitation on completeness of coverage was the author's own time. There seems to be no other reason in principle why coverage could not be extended to all the outliers or, indeed, to the full sample of plants. ${ }^{31}$ In the following analysis of the interviews, plant managers in the early or later groups, and the sign of the residual error, are distinguished by (pos. 82), (pos. 90), or (neg. 90).

\section{Role of Employees and Extent of Data Errors}

An important aspect of the survey is the emphasis by respondents on equipment characteristics and reliability as primary determinants of workforce size and composition. This corroborates the basic distinction in much of the electric utility literature between "ex

31. In the early interviews an attempt was made to contact all 17 plants, and plants were excluded only when repeated attempts failed to reach the plant manager. The plants for the later interviews were selected at random, in the sense that one or more phone calls were placed to every plant on the list of 30 . The first 12 plants where the plant manager could be contacted were included; the rest are excluded because of no answer, busy signals, managers who were in meetings or on vacation. 
Productlvity in Electricity Generation, Page 41

ante" investment decisions and "ex post" operating decisions, the latter allowing plant managers little freedom to deviate from fixed capital-energy-labor input ratios. Indeed, a striking feature of the data is the tendency for a given plant to experience the same capacity, heat rate, and employment for several years and sometimes decades, with utilization being the only variable experiencing marked year-to-year fluctuations.

The first step in each telephone call was to verify the basic information contained in our data file on plant vintage, units, capacity, and employment. Managers were questioned closely in cases where employment had increased noticeably in the last five years of the sample period without an increase in capacity. In every case but one where a discrepancy was reported, the error could be traced to the government document that provides the source data.

What do plant employees do? Paul Wade at the Bull Run (TN) 1967-vintage TVA plant (pos. 82) decomposed his 1982 work force of 227 people as consisting of 70 involved in maintenance, 55 in operations, 50 in coal handling, 25 in specialized work involving instruments and water quality control, and 15 in administrative capacities (this accounts for 215 of the 227). 22 percent of the work force is cited as being involved in coal handling, very close to the estimated 23 percent employment penalty of coal plants relative to gas plants in column (1) of Table 6. Confirmation of this figure also comes from Tim Lovette of the Danskhammer (NY) plant (pos. 90), which shifted from oil and gas to coal in 1986-87 and was forced to raise employment from 101 to 126 as a result. 
Productivity in Electricity Generation, Page 42

\section{Omission of Variables}

Some, but not all, of the plant managers seemed aware that the level of employment at their plants was "relatively high" or "relatively low" and had ready explanations, always involving additional factors that were not identified in the data set. An examination of the following list of factors is somewhat disturbing for the econometrician, in that it suggests that the list of "left-out" variables assembled from a complete set of interviews might exhaust the available degrees of freedom even in this rich data set:

1. Gas Turbine Unit. Three of the plant managers reported that their employment rolls included people involved in operating and maintaining gas turbine capacity that is not included in the basic data source which covers only steam units. As it happens, all three of these pre-1968 plants added the gas turbine capacity in 1968 or afterward, thus contributing to the significance of the positive 1968-78 time shift coefficient. In every case gas turbine units are used for peaking purposes but nevertheless can add a significant number of employees.

2. Joint Products. The Warwick (IN) plant was built jointly with an Alcoa aluminum smelter and on average 85 percent of the plant's electric output goes to the smelter rather than to other electric company customers. The particular location and identity of the principal customer would not be important if it were not for the fact that the plant's employment register includes an unspecified number providing specific services to Alcoa, including steam and water treatment services.

3. Joint Maintenance and Engineering Senvices. In the later group of interviews all 
plant managers were questioned about joint maintenance and whether they imported or exported employees. The most common pattern was sharing actoss plants within the firm with no implications for the regression results if imports of employees for the subject plant's overhaul period are balanced by exports of employees to service other plants. Ron Kilman of the Sooner (OK) plant (pos. 90) stated that he sometimes exported 4-10 employees for minor overhauls and 20-25 for major overhauls, out of a total staff of 220. Melanie AdamsMiller of the Anclote (FL) plant (neg. 90) gets along with only about half the predicted number of employees, partly because her firm has a traveling maintenance crew of 100-120 people who perform overhauls on her plant. Similarly, shift supervisor Wally Ghilani of the Harrison (WV) plant (neg. 90) reports that major maintenance at his plant is performed by "mobile maintenance gangs" employed by a specialist service firm, not by his own utility. Guy Pepipone of the Sammis (OH) plant (pos. 90) was the only manager reporting a major component of employees who performanced services for other plants in the same firm; in his case fully 30 percent of the employees perform engineering and planning services on a per-service fee basis.

4. Isolated location. In the later group seven of the 15 positive outliers, and none of the negative outliers, are located in five mountain-region states (Nevada, Arizona, New Mexico, Wyoming, and Montana), largely because isolated plants are required to be more self-sufficient. The role of this and other omitted variables related to isolation can be illustrated by the example of a consistent top-five outlier, the Navajo (AZ) plant (pos. 82). The 1974-vintage plant is listed as having 615 employees in contrast to the predicted level 
of 146 in 1978, and by 1987 this had risen to 752 employees vs. a predicted level of 310 . The plant is in Page, Arizona, near the Arizona-Utah line and east of the Grand Canyon. It faces three separate problems that are directly related to its location. First, its employees run the plant's own railroad to move coal 78 miles from the mine. This factor alone accounts for 100 extra employees. Second, the plant is 300 miles from both Phoenix and Salt Lake City and cannot rely on outside contractors for special maintenance functions. Thus, an undetermined part of its excess staff is explained by the need to include sufficient maintenance employees to handle virtually any conceivable job. A related factor is the dependence of the area on the plant, so that any outage must be repaired more promptly than "plants in the east." Third, the environmental regulations in that area are particularly demanding. Isolation is indirectly related to the high level of employment at the Mohave (NV) plant (pos. 90), due to the use of "slurry" (liquid-form) coal brought in by pipeline. The mechanical process of extracting the water from the coal not only requires extra operating workers, but also "wears the heck out of everything," thus requiring extra maintenance personnel, according to assistant plant manager Don Wilson.

5. Old Building. The data do not distinguish between the vintage of the structure and the vintage of the equipment. Mr. Decker, the Kearney (NJ) plant manager (pos. 82), attributed part of his high employment level to the fact that his steam equipment, of which 52 percent of the current capacity was installed in 1953 and the rest in 1926, was housed in a 1926 building, which required "more maintenance" than a postwar building of similar size.

6. New Units After Sample Period. In the cases of two plants in the early group, a 


\section{Productlvity in Electrlcity Generation, Page 45}

jump in employment in the $1977-78$ period was explained by the installation of new units that were actually completed in 1979 or 1980 , after the end of the sample period. If also true after the end of the extended 1948-87 sample period, this factor could account for part of the time shift effect.

7. Plant Configuration. Another omitted determinant of employment was identified by Ron Kilman of the Sooner plant. Units of a given size boiler and generator can be fitted with coal silos of different sizes, and small-sized silos of the type at his plant must be refilled every 6-8 hours, as contrasted with other plants of the same size fitted with "24-hour" silos.

\section{Misgauged Maintenance Burden}

A consistent explanation of rising employment relative to capacity was the incorrect anticipation of maintenance requirements. Staffing levels were increased when it was discovered that "the previous force wasn't adequate" and when "deferred maintenance began to build up." This factor would not tend to contribute to our time shift coefficients if it had operated consistently over the postwar period, but it appears to have been concentrated in post-1968 plants. An example of the contribution of maintenance to the time shift coefficient is reported by Guy Pepipone of the Sammis (OH) plant (pos. 90). After installation of seven units over the period 1959-71, employment at his plant had remained at the 450 level through 1978. But then critical maintenance problems began to develop with units 5, 6, and 7 (vintages 1966-71), and employment ballooned to 860 by the early 
1980 s without any further change in capacity. ${ }^{32}$ In this particular case employment overshot and was thereafter steaily reduced by attrition to about 725 in 1990 .

Unhappy experiences were reported by Don Wilson of the 1971-vintage Mohave plant. A steam pipe explosion cut output for 1985 almost in half from the average of 1984 and 1986. Unanticipated problems with turbine blades caused substantial shutdowns while the turbine rotors were rebuilt. ${ }^{33}$ Related to the role of unanticipated maintenance problems was the shifting division of responsibilities between equipment manufacturers and utilities for trouble-shooting and retrofitting. Guy Pepipone reported that "we're not getting as much help from manufacturers as we used to," and he and others attributed this to financial tightness at the manufacturing firms which were faced with a dearth of orders for new equipment after the mid-1970s. Bob Arambel of the Naughton (WY) plant (neg. 90) cited maintenance problems with a coal-pulverizing unit that was "underdesigned" with a firebox that was too small, causing the unit to operate at a too high a velocity and develop "boiler tube erosion."

\section{Environmental Regulations}

The most plausible cause of the adverse time shift effect in our employment regressions is the role of environmental regulations, which fell on electric utilities more beavily than any other industry. Standards for emissions standards dating back to 1970

32. These were early examples of a new generation of Babeock and Wilcox boilers, and numbers 6 and 7 were supercritical (sce below).

33. The increased size of units created substantial problems with turbine blades, as documented by Hirsch (1989, pp. 105-8). 


\section{Productivity in Electricity Generation, Page 47}

affected labor productivity at generating plants by forcing plants to shift from high-sulfur to low-sulfur fuel having lower energy content, thus requiring more fuel to be handled per unit of electricity output. Most plants had to install additional capital equipment in the form of electrostatic precipitators or scrubbers, which substantially raised capital cost and also required the addition of maintenance employees. The effects of environmental regulations differ widely in their impact on each plant due to differing emissions standards in different regions (Gollop-Roberts, 1985), different rules applied to plants of different vintages, and variations in the emissions-creating characteristics of the three fuels (coal, gas, and oil).

Among our outlier plants the most common air pollution control device is one or more electrostatic precipitators, installed at seven of the 12 plants in the early group and eight of the 12 in the later group (which also contained two plants with scrubbers and two with no emissions control equipment). Although some managers claimed that precipitators were not a major extra source of maintenance employment requirements, 35-40 extra people, or 12-13 percent of the work force, were attributed to precipitators at the Gallatin (TN) plant (pos. 82). There first-generation precipitators had proven to be inadequate when emissions requirements were raised from the 95 to the 99 percent level, and new equipment four times as large had to be installed. The need for a quantum jump in the size of precipitators was augmented by the widespread shift to low-sulfur coal. Apparently this type of fuel requires extra precipitator capacity.

At the La Cynge (MO) plant (pos. 82), vintage 1973, two units of roughly the same size experienced quite different employment requirements connected with air pollution 
equipment. At the first unit, installed in 1973, local high sulfur (5 percent) coal was used, and a "tail-end scrubber" was installed. This required "probably $40-45$ people" ( 25 percent of the average 1974-75 work force) for operations and maintenance. ${ }^{34}$ On the second unit, installed in 1977, low sulfur coal was used, and an electrostatic precipitator instead of a scrubber was included. Extra maintenance requirements of the precipitator are claimed to be only a single person. The tradeoff involves a much higher cost of coal for the second unit. At the Sommers (TX) plant (pos. 82) scrubbers installed after 1978 are cited as a "high cost maintenance item" that create "sludge that is hard to get rid of." Plant manager Jerry Godwin at the San Juan (NM) plant (pos. 82) reported that scrubbers had been installed on all four of the units installed between 1973 and 1982 , as well as a "\$93,000,000 zero-discharge water management system," and that fully 17 percent of the level of electric rates charged by his company could be attributed to the expenses of air and water pollution control.

Tony Leavitte of the Gardner (NV) plant (pos. 90) attributed the employment of 50 60 people of his 275-person workforce, or 18-22 percent, to environmental regulations. These include not only the operation and maintenance of scrubbers, but also water treatment "evaporation ponds:" Bob Arambel of the Naughton (WY) plant attributed only 5 percent of employment to environmental regulations, this smaller number reflects the fact that only one of his three units has a scrubber.

A uniquely local form of regulation was cited by Ron Kilman of Sooner. Beginning

34. The La Cygne plant is the subject of Weaver (1975), which highlights the unanticipated maintenance problems created by scrubbers. 
Productivity In Electricity Generation, Page 49

in 1987 all utility plants in Oklahoma must use 10 percent Oklahoma-mined coal, requiring another feed belt and new automatic controls for blending the Oklaboma coal with the Wyoming coal that was previously used exclusively. Perhaps the extreme case of minimal impact of environmental regulations is the Anclote (FL) plant (neg. 90), which has no pollution control equipment and manages the burden of obtaining "innumerable permits" and training about regulations with a fixed and relatively small staff.

How do these anecdotes compare with the magnitude of the "time shift" effect displayed above for the employment equations? To take the equation for coal-using plants with vintage averaging (Table 7, col. 2), there was a shift in the time coefficient from -0.019 for $1948-67$ to +0.026 for $1968-87$, for a net deterioration of 0.045 points per year. This would imply that by 1987 fully 85 percent of additional employment could be attributed to the time shift effect. Since no plant manager cited work force additions connected with pollution control equipment exceeding 25 percent, at a maximum one could attribute only about one-third of the time shift effect to environmental legislation, and probably less. This leaves the remainder to be attributed to data errors, unanticipated maintenance, and other undetermined causes. A hint of one of these causes was provided by Jerry Chambers of the Stout (IN) plant (neg. 90), who described an overall shift toward a less productive and more careful response to events: Tve been doing this for $26-27$ years. In those days our main concern was making electricity. If you had a leak, you'd pull off the insulation, patch it, and the repair would be done. Now, you have to call in a contractor to take air samples, you have to be inspected, and it takes two days to do what used to take two hours." 


\section{Productlvity in Electricity Generation, Page $\mathbf{5 0}$}

\section{Diminishing Returns to Technical Advance}

The interviews revealed substantial evidence of the reversal of vintage-specific technical improvements in the late 1960s and 1970s. The most common feature of the interviews was the uniform report that the technical advance in the 1960 s to "supercritical" units (having a pressure of more than 3200 pounds per square inch) had encountered an unanticipated econnmic barrier. These units cost too much to build and to maintain, and by 1977-78 subcritical designs were once again the dominant form of new installations (see the discussion in Part III above).

Plant managers were outspoken in condemning supercritical units. In comparing his 1973 supercritical unit to his earlier and smaller subcritical units, Jim Smith of the Gaston (AL) plant (pos. 82) commented that the newer unit "blows real crud" that adds substantial maintenance expense. The earlier units are easier to maintain and produce "no filth." Plant manager Cathcart of the Homer City (PA) plant (pos. 82) reported that the supercritical units had been introduced in the early 1960 s as the next step in the technical progression that had steadily increased thermal efficiency. But they brought with them "complex valving" with an associated "burden of maintenance." Equipment designers had planned the supercritical units in a "laboratory and had not anticipated the effects of cold and hot weather and of fly ash. The real world is not a laboratory." James Morrison of the Mercer (NJ) plant (pos. 82) commented that most companies had experienced a poor operating record with supercritical units, with a "forced outage rate bigher than anticipated." Carl Higgs of the La Cynge (MO) plant (pos. 82) contrasted his "supertroublesome" Westing- 
house Unit \#l with his much more reliable and less labor-intensive General Electric Unit \#2. On the same Westinghouse unit the turbine blades had a tendency to keep "falling out. $^{\text {n35 }}$ The interviews of negative outliers revealed only one instance of a supercritical boiler, adding further evidence that few if any supercritical boilers achieved a high level of labor productivity. ${ }^{36}$

Advances in metallurgy, which have been credited for allowing larger scale and higher temperatures and pressures, apparently were unable to keep ahead of the needs of plant designers. Wally Ghilani of the Harrison plant cited leaks, overheating, and "fishmouth stress" in his supercritical boilers, as well as the complexity introduced by "so many relays, so much protection" that the problem of false alarms was "phenomenal." Paul Wade of Bull Run also reported gas leaks, which he attributed to "phased pressurized furnaces," "a design that we learned just didn't work." Cathcart of Homer City described considerable extra maintenance connected with "tears in casing" that were related to high furnace pressure.

Most managers agreed that economies of scale had been exhausted. As shown above in Table 4, the average capacity of new plants reached a plateau at $850 \mathrm{MW}$ by 1972-74 and increased little after that. Carl Higgs of La Cynge felt that the optimal size of a single unit

35. Interestingly, Westinghouse officials attribute part of their problems to inadequate research and development expenditures in the 1960s. See "The Turbine Troubles that Plague Westinghouse," Business Week, April 6, 1984, pp. 5455.

36. Another case is the Harrison (WV) plant, which is labelled here erroneously as a negative outlier only because the government data source greatly understated employment in three of the five years $1983-87$ (as reported above). 
was $600-650 \mathrm{MW}$, and Paul Wade of Bull run stated that "1000-1100 is as large as you can go." Cathcart of Homer City claimed that manufacturers had sold larger units in the 1960 s by "extrapolating the features of smaller units and convincing users that they didn't require extra maintenance."

In another comment with important implications for practitioners of the hedonic regression technique, Cathcart contrasted the features of his two $600 \mathrm{MW}$ supercritical units (vintage 1969) with his $650 \mathrm{MW}$ subcritical unit (vintage 1977). In putting out bids for the earlier units, his company had emphasized low cost and had specified only a few basic specifications-temperature, pressure, etc. In contrast, the bidding procedure for the newer unit involved much more detailed specifications, chosen to avoid the maintenance problems encountered in the earlier units. "Wall thickness on tubes was increased from 150 to 200 mils, the maximum velocity of the gas stream was reduced from 85 to $55, "$ and so on. A hedonic regression explaining equipment prices of the type developed in Gordon (1990, Chapter 5) and Joskow-Rose (1985) would treat all three units as essentially identical and would overstate the price increase from 1969 to 1977. Continuing the theme of "learning by doing," James Agnew at Cumberland attributed his ability to reduce plant staffing to a gradual process of modifying his 1973-vintage "prototype units" (two enormous units of 1300 MW each). The furnace had been changed, generating surface had been added to boilers, and precipitator surface had been added.

The later group of interviews did not have quite as gloomy a tone as those conducted earlier. In fact, there are some signs in the interviews (although not yet in our data) that 
the worst may be over. Several managers cited enthusiastically the role of computerized controls, which can analyze and predict maintenance problems before they occur. Don Wilson at Mohave raved above his training simulator, which could train operators how to handle every eventuality without endangering either of his two large $790 \mathrm{MW}$ units. Tony Leavitte of Gardner cited improved control systems and water treatment equipment as allowing him to reduce his staff by about three percent over the most recent two years. He was also enthusiastic about his CRT-equipped control room which allowed operators to plot the "trend" of numerous variables like temperature and pressure and spot potential problems in advance.

How do plant managers of negative outlier plants explain their low level of employment? Consistent with my earlier research on airlines (1965), managers with poor productivity performance blame outside forces, while managers with a high level of productivity attribute their performance to themselves and their workers. James Stape of the.San Tan (AZ) plant (neg. 90) stated flatly that "we're good" and that his employees were a "close-knit" group, the "opposite of Navajo," a plant owned by the same firm that is at the top of our positive outlier list. Rick Smith of the Fort Phantom (TX) plant (neg. 90) cited "the quality of our guys." Tim Lovette attributed the performance of his Danskhammer plant to a "company philosophy to be lean up and down."

Overall, the interviews add up to a convincing case in support of the "depletion hypothesis." Advances in productivity in the first two decades of the postwar era (and before 1948 as well) were made possible by technical improvements that allowed for higher 
Productlvity in Electrlcity Generation, Page 54

scale, temperatures, and pressure, but this process seems to have come to an end in the late 1960s. The technical barrier represented by supercritical pressure may be likened to the barrier of supersonic speed in the aircraft industry. Coincidentally, the postwar upsurge in aircraft scale and speed also seems to have come to an end around 1970 (Gordon, 1990, Chapter 4). One ray of hope is that, having deteriorated so much from the optimism of 1965 to the gloom of 1982, the conditions for productivity growth do not seem to have deteriorated further during the rest of the 1980s. Plant managers viewed themselves as operating in a difficult environment, but with few exceptions felt that the environment had remained stable over the past five years.

\section{CONCLUSION}

This paper attempts to decompose the sources of the slowdown in labor productivity growth in the steam-electric generating industry among a number of possible causes. Particular emphasis is placed on the separate roles of economies of scale, embodied technical change, and disembodied technical change. The major conclusions can be divided among methodology and substance.

\section{Methodology}

1. Data sets that provide information on individual plants observed along the two dimensions of vintage and age are particularly useful in studying the sources of growth. Cross-section data also allow for quantification of scale effects, shifts in the locational mix, and other sources of productivity change that are lumped together as an unexplained 


\section{Productivity in Electricity Generation, Page 55}

"residual" in aggregate studies.

2. In microeconomic research on data sets that identify individual observations, e.g., plants or firms, a study of a mysterious phenomenon like the productivity slowdown can benefit from direct personal or telephone contact with plant or firm representatives. Such contact can reveal errors in data or interpretation at previous stages of a particular research study, and can add detail to flesh out an abstract academic conjecture, e.g., the "depletion bypothesis."

3. Data sets that identify establishments and firms separately allow for a detailed analysis of "within" establishment and "between" establishment and firm effects. This is an unambiguous advantage of establishment data over the firm data used in many studies, and is only partly offset by measurement errors when separate plants within a firm share employees.

\section{Substantive Results}

The steam-electric utility industry experienced a much sharper slowdown in the growth of labor productivity after 1968 than the U. S. economy as a whole. The study identifies four main sources of the growth slowdown, each of which appears to have operated with more severity than in the whole economy.

1. A sharp drop in plant utilization occurred after the late 1960 s, resulting both from the two oil shocks that raised the relative price of electricity, and from the slowdown in output and productivity growth in the rest of the eccnomy. Both of these factors caused the growth rate of electricity demand to slacken sharply in the mid-1970s immediately after 


\section{Productivity in Electricity Generation, Page 56}

utilities had been on a binge of purchasing equipment. Our employment regressions imply that 92 to 98 percent of any change in utilization flows through to a change in labor productivity in the same direction.

2. The growth of average plant size and unit size decelerated sharply after the late 1960s. Before 1968 rapid increases in the scale of new plants, together with a relatively small elasticity of employment growth to scale growth, allowed for productivity improvements. Earlier increases in scale resulted from incremental improvements in technology, particularly in metallurgy. After 1968, however, capacity growth appears to have encountered technical constraints. The impact of this source of the productivity slowdown is consistent with the "depletion hypothesis" of the overall economy-wide slowdown.

3. There was a disappearance in productivity gains associated with newer plants of a given capacity, i.e., the "vintage shift" effect. Plant designers appear to have run into unanticipated technical barriers that caused them to build plants that were too large, too complex, and which required a high and unanticipated level of maintenance expenditures.

4. Beyond the contribution of equipment manufacturing problems to the productivity slowdown, after 1968 the utility industry encountered problems in operating pre-existing equipment. Less than one-third of this "time specific" effect can be attributed to environmental legislation. An undetermined part of the rest is due to a previously unanticipated maintenance backlog on plants of earlier generations built when technology arrived at the apparent frontier in the late 1960 s and early 1970 s.

The regressions in this paper attempt to explain the relation of employment to output 
by holding constant numerous characteristics of individual plants. If the only cause of the slowdown in labor productivity growth in the electric utility industry had been a deceleration in the rate of technical change embodied in new equipment, this would be imply that there had been no slowdown in the growth rate of total factor productivity (TFP), since all of the declining growth rate of output per hour would be explained by an equal-sized decline in the growth rate of capital's contribution to output. Another implication of this hypothetical finding would be that the source of the productivity problem originates not in the electric utility industry but in the electric equipment industry within the manufacturing sector.

However, a substantial fraction of the overall slowdown in labor productivity in electricity generation can be linked to factors other than embodied technical change, and thus did occur within the utility industry itself. In contrast to labor productivity growth for our sample of plants, which exhibited a deceleration from 7.5 percent per annum in 1948-68 to -0.4 percent per year in $1968-87$ (for a total slowdown of 7.9 points), TFP growth using official NIPA deflators for the capital stock slowed from 3.6 to -1.8 percent per year (for a total slowdown of 5.4 points). When the deflator of electric generating equipment is measured by a hedonic index of the type developed by Gordon (1990) and Joskow-Rose (1985), TFP slows from 1.8 to -2.7 points, for a slowdown of 4.5 points. ${ }^{37}$ Not coincidentally, the slowdown of 4.5 points is very close to the time shift coefficients in our all-fuel equations in Tables 6 and 7, ranging from 3.6 to 4.7 points. The fact that TFP slows less

37. This calculation is not shown in the paper to save space. Output, employment, and nominal equipment cost refer to our sample of plants. The hedonic equipment deflator comes from Gordon (1990), Table 5.9, col. (2), recalculated to 1986 from our revised data. 
Productlvity in Electricity Generation, Page 58

than average labor productivity, and that TFP growth in the pre-1968 period was so much slower than the growth of average labor productivity, underlines the responsibility of capital input growth for much of the industry's outstanding achievements in the first half of the postwar period and for its abysmal performance since then.

This paper represents only a beginning in studying the industry's productivity problems. Much of the large "time shift" effect remains unexplained. A more complete investigation would incorporate into the data more information on the design characteristics of individual plants, aithough our interview study suggests that many explanatory factors will inevitably be overlooked. A wider interview survey might reveal a more specific estimate of the impact of air and water pollution control legislation. Comparisons with foreign countries, using a combination of econometrics and interviews, might reveal the relative roles of design philosophy, equipment reliability, operating procedures, and environmental regulation in explaining why the European and Japanese electric power industries have not exhibited deteriorating performance to the same extent as the American industry. ${ }^{33}$ Finally, one might hope that the mixture of econometric and interview techniques utilized here could be fruitfully employed in other industries, and that economists interested in production economics might devote more attention to the possibility of interviewing the business executives whose behavior they are trying to explain.

38. The more cautious design philosophy of European manufacturers during the postwar years is discussed by Hirsch (1989), pp. 3, 75 . 
Productivity In Electricity Generation, Page 59

\section{REFERENCES}

ATKINSON, SCOTT E., and HALVORSEN, ROBERT (1984). "Parametric Efficiency Tests,

Economies of Scale, and Input Demand in U. S. Electric Power Generation," Intemational Economic Review, vol. 25 (October), pp. 647-62.

BAIly, MARTIN N. (1981) "Productivity and the Services of Capital and Labor," Brookings Papers on Economic Activity, no. 1, pp. 1-50.

BarzeI, Yoram (1964). The Production Function and Technical Change in the SteamPower Industry," Journal of Political Economy, vol. 72, April, pp. 133-50.

BRUNO, MICHAEL and SACHS, JEFFreY (1985). The Economics of Worldwide Stagflation. Cambridge, MA., Harvard University Press.

BUSHE, DENNIS M. (1981) "An Empirical Analysis of Production and Technology Using Heterogeneous Capital: Thermal Electric Power Generation, unpublished Ph.D. dissertation, New York University, October.

CHRISTENSEN, LAURITS R., and GREENE, WILLIAM H. (1976). "Economies of Scale in U.S.

Electric Power Generation," Joumal of Political Economy, vol. 84, August, pp. 655-76. Cowing, Thomas G. (1970) "Technical Change in Steam Electric Generation: An Engineering Approach," unpublished Ph.D. thesis, University of California, Berkeley. (1974). "Technical Change and Scale Economies in an Engineering Production Function: The Case of Steam Electric Power," Joumal of Industrial Economics, vol. 23, December, pp. 135-52. 


\section{Productivity in Electricity Generation, Page 60}

, SMALL, JEFFrEY, and STEVENSON, RODNEY E. (1981). "Comparative Measures

of Total Factor Productivity in the Regulated Sector: The Electric Utility Industry," in Cowing and Stevenson (1981), pp. 162-77.

, and SMTH, KERRY V. (1978). "The Estimation of a Production Technology: A

Survey of Econometric Analyses of Steam-Electric Generation," Land Economics, vol 54, no. 2, May, pp. 156-86.

, and Stevenson, RodNEy E., eds. (1981). Productivity Measurement in

Regulated Industries. New York: Academic Press.

DENISON, EDWARD F. (1985). Trends in American Economic Growth, 1929-82. Washington: the Brookings Institution.

GOLLOP, FRANK M., and ROBERTS, MARK J. (1981). "The Sources of Economic Growth in the U.S. Electric Power Industry," in Cowing and Stevenson (1981), pp. 107-43. (1983). "Environmental Regulations and Productivity Growth: The Case of

Fossil-Fueled Electric Power Generation," Joumal of Political Economy, vol. 91, November, pp. 654-74.

(1985). "Cost-minimizing Regulation of Sulfur Emissions: Regional Gains in

Electric Power," Review of Economics and Statistics, vol. 67, February, pp. 81-90. GORDON, ROBERT J. (1965) "Airline Costs and Managerial Efficiency," in Transportation

Economics, Universities-National Bureau Conference Volume, New York, pp. 61-92. (1990). The Measurement of Durable Goods Prices. Chicago: University of Chicago Press for NBER. 
Productivity In Electricity Generation, Page 61

HIRSH, RICHARD F. (1989). Technology and Transformation in the American Electric Utility Industry. Cambridge, U.K.: Cambridge University Press.

JoRgenson, Dale W. (1984). "The Role of Energy in Productivity Growth," The Energy Joumal, vol. 5 (July), pp. 11-25.

JOSKOW, PAUL L and ROSE, NANCY L (1985). "The Effects of Technological Change, Experience, and Environmental Regulation on the Construction Cost of Coal-burning Generating Units, ${ }^{,}$Rand Joumal of Economics, vol. 16, Spring, pp. 1-27. and RICHARD SCHMALENSEe (1983). Markets for Power: An Analysis of Electric

Utility Deregulation. Cambridge, MA.: The MIT Press.

KENDRICK, JOHN W. (1961). Productivity Trends in the United States. Princeton, N.J.:

Princeton University Press for NBER.

KOMIYA, R. (1962). "Technical Progress and the Production Function of the United States Steam Power Industry," Review of Economics and Statistics, vol. 44, pp. 156-66.

MOORE, F.T. (1959) "Economies of Scale: Some Statistical Evidence," Quarterly Journal of Economics, vol. 73, May, pp. 232-45.

NERLOVE, MARC (1963). "Returns to Scale in Electricity Supply," in C. Christ, ed., Measurement in Economics (Stanford: Stanford University Press), pp. 167-98.

Nordhaus, William D. (1980). "Policy Responses to the Productivity Slowdown," Federal Reserve Bank of Boston, The Decline in Productivity Growth, Conference Series 22, pp. 147-72.

(1982). "Economic Policy in the Face of Declining Productivity Growth," 


\section{Productlvity In Electriclty Generation, Page 62}

European Economic Review, vol. 18, May/June, pp. 131-58.

NORSWORTHY, J.R., HARPER, MICHAEL J., and KUNZE, KENT (1979). "The Slowdown in

Productivity Growth: Analysis of Some Contributing Factors," Brookings Papers on Economic Activity, no. 2, pp. 387-432.

PAKES, ARIEL (1983). "On Group Effects and Errors in Variables in Aggregation," Review of Economics and Statistics, vol. 65, February, pp. 168-73.

RASCHE, ROBERT, and TATOM, JOHN (1981). "Energy Price Shocks, Aggregate Supply, and Monetary Policy: The Theory and the International Evidence," Karl Brunner and Allan H. Meltzer, eds., Supply Shocks, Incentives, and National Wealth, CarnegieRochester Conference Series on Public Policy, vol. 14, pp. 9-93.

ROSE, NANCY L and JOSKOW, PAUL L. (1990). "The Diffusion of New Technolgoies: Evidence from the Electric Utility Industry," RAND Joumal of Economics, vol. 21, no. 3, Autumn, pp. 354-73.

SCHMALENSEe, Richard and Joskow, PAUl L. (1985). "Estimated Parameters as Independent Variables: An Application to the Costs of Electric Generating Units," MIT Sloan School of Management working paper 1575-84, February.

Weaver, Paul H. (1975). "Behind the Great Scrubber Fracas," Fortune, February, pp. 10614.

WILLS, HUGH R. (1978). "Estimation of a Vintage Capital Model for Electricity Generating," Review of Economic Studies, vol. 45, no. 141, October, pp. 495-510. 
Productivity in Electricity Generation, Page 63

\section{DATA APPENDIX}

\section{Data Source}

All data were obtained from the annual publication of the U. S. Energy Information Administration. In 1978 the title of the publication changed from "Steam-Electric Plant Construction Cost and Annual Production Expenses" to "Thermal-Electric Plant and Construction Cost and Annual Expenses," and then in 1982 to "Historical Plant Cost and Annual Production Expenses for Selected Electric Plants." In prior years the publication was issued by predecessor agencies, particularly the Federal Power Commission.

The data file contains plants observed from 1948 to 1987, but vintages of these plants extend back to the early years of the century. Data for years through 1971 were obtained from Thomas Cowing, and data for years since 1972 were added by successive research assistants. Most plants added to the original data set had vintage of 1972 or newer, with six exceptions. Some changes in plant identification also occurred as a result of merging of units previously considered as separate plants. The complete data set contains 7701 observations, with 29 basic variables per observation (including dummies for fuel type, construction type, and regional location), and a number of additional constructed variables.

The 1982 change in the title of the data source also involved a downsizing of the data from a nearly complete census to a sample. Plants excluded in 1982 and subsequent years amounted to 25 percent of the plants in the 1981 population, but only 9 percent of the total output of the 1981 population, since the excluded plants were on average only one-third as 


\section{Productivity in Electricity Generation, Page 64}

large (measured by either capacity or output) as the average for the 1981 population.

\section{Editing and Adjustments}

The total sample of 7701 was edited down to the 6674 observations used in the initial regression reported in the first column of Table 5. Several criteria were used in editing and apply to the entire data set, not just the new post-1971 observations added for this project.

1. Cleaning. Observations were excluded when (a) the utilization rate was below 5 percent, (b) when data seemed to be of the wrong order of magnitude, (c) when plant statistics were reported jointly with a nuclear or gas turbine plant, or (d) when data were missing for specific variables needed for a regression. Particular care was taken to make sure that the location, plant construction, and vintage dummies were identical from year to year for each plant, and that there were no implausible jumps in data on capacity and the number of units. In years when plant capacity was missing, this could sometimes be calculated from data on output and the utilization rate.

2. Adjustments. There were six cases when two or three plants shared a single listed employment figure, and in these cases all variables were aggregated over the plants in question to form a single observation for the hybrid plant. In some recent years data are reported as applying to a percentage "P" of the plant, and quantity data are then divided by "P". Comparisons with adjacent years are made to determine whether "P" applies to all variables, especially employment data. Where some units were indoors and some outdoor, the construction plant dummy was coded "semi-outdoor."

3. Configuration Changes. Plants were included only in the first full year of 
Productivity in Electricity Generation, Page 65

operation, that is, the year after the vintage year, and were also excluded for years $t-1$ and $t$ whenever there was a change in year $t$ in either the number of units or a non-negligible change in capacity. This exclusion principle applies both to increases and decreases in units and/or capacity.

4. Average Vintage. Most of the regression results refer to the "average" vintage of a plant. This is simply the average of the vintage for each unit in the plant. A plant installed in 1955 with 5 units that adds an additional unit in 1966 would be coded as vintage 1956.8, rounded to 1957 . 

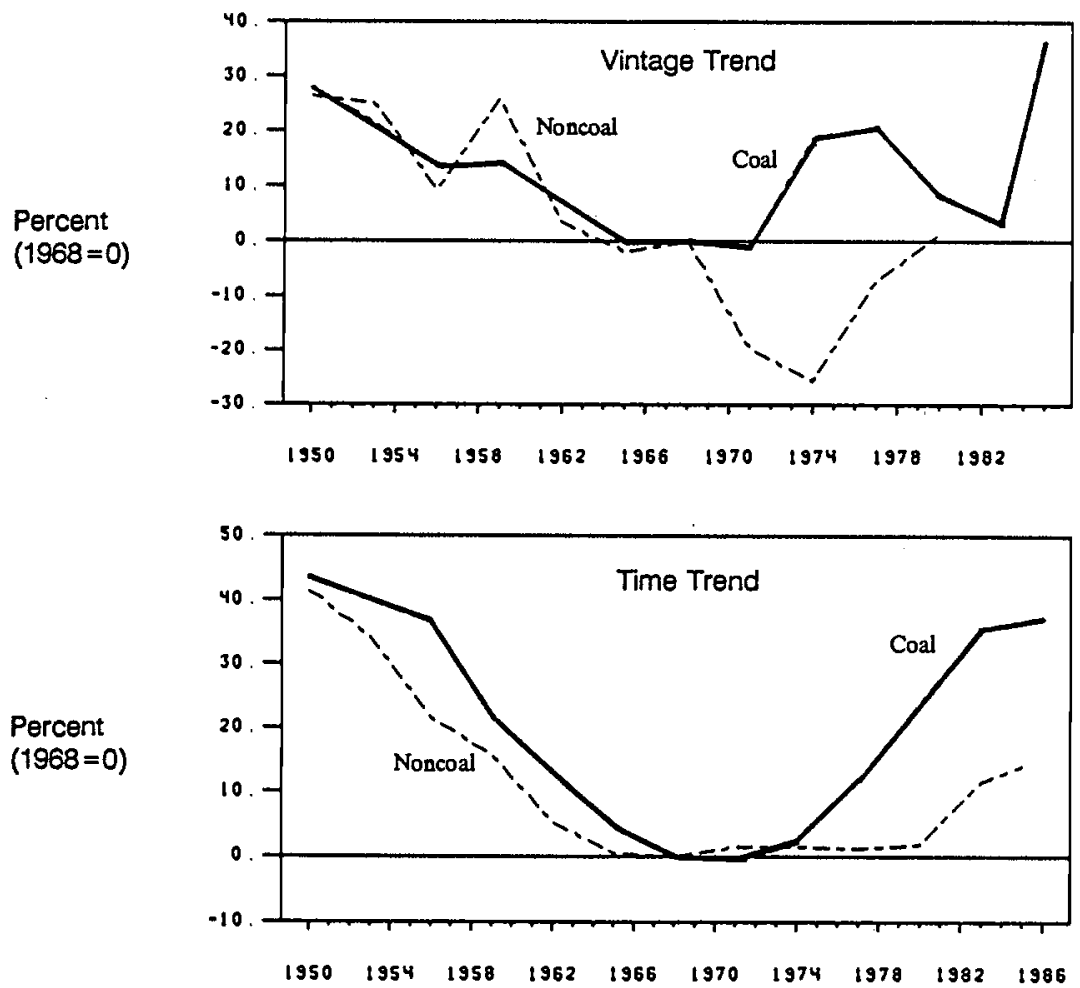

FIGURE 1

Percentage Deviation of Vintage and Time Trend Coefficients from 1968 Level,

Employment Regression, Coal and Noncoal Plants 


\section{TABLE 1}

Output Per Hour Nonfarm Business and Electric Utilities, and Real Price of Electricity, Various Intervals,

$$
1899 \text { - } 1988
$$

\begin{tabular}{||cccc|}
\hline Interval & $\begin{array}{c}\text { Output Per Hour } \\
\text { Nonfarm Business }\end{array}$ & $\begin{array}{c}\text { Output per Hour } \\
\text { Electric Utilities }\end{array}$ & $\begin{array}{c}\text { Real Price of } \\
\text { Electricity }\end{array}$ \\
\hline $1899-1923$ & $(1)$ & $(2)$ & $(3)$ \\
$1923-1948$ & 2.1 & 5.7 & -7.4 \\
$1948-1963$ & 2.1 & 6.1 & -6.7 \\
$1963-1973$ & 2.6 & 6.8 & -1.3 \\
$1973-1988$ & 2.2 & 5.5 & -0.8 \\
\hline
\end{tabular}

Sources by column:

(1) 1899-1948, Kendrick (1961), Table A-XXIII, pp. 338-40, linked in 1948 to Economic Report of the President, 1990, Table C-46.

(2) 1899-1953, Kendrick (1961), Table H-VI, pp. 590-91, linked in 1953 to NIPA Table 6.2, line 49 (electric, gas, and sanitary services), linked in 1958 to BLS for electric utilities (1958-63 from BLS Bulletin 2296, February 1988, Table 261, p. 142 and 1963-88 from BLS Bulletin 2349, February 1990, Table 279, p. 150).

(3) 1899-1970, Hirsch (1989), Figure 7, p. 9, linked to NIP A, Table 7.10, line 50, divided by Table 7.1, line 1 . 


\section{TABLE 2}

Selected Figures on Industry Output, Productivity and Prices,

Levels and Growth Rates, Selected Intervals, 1948-88

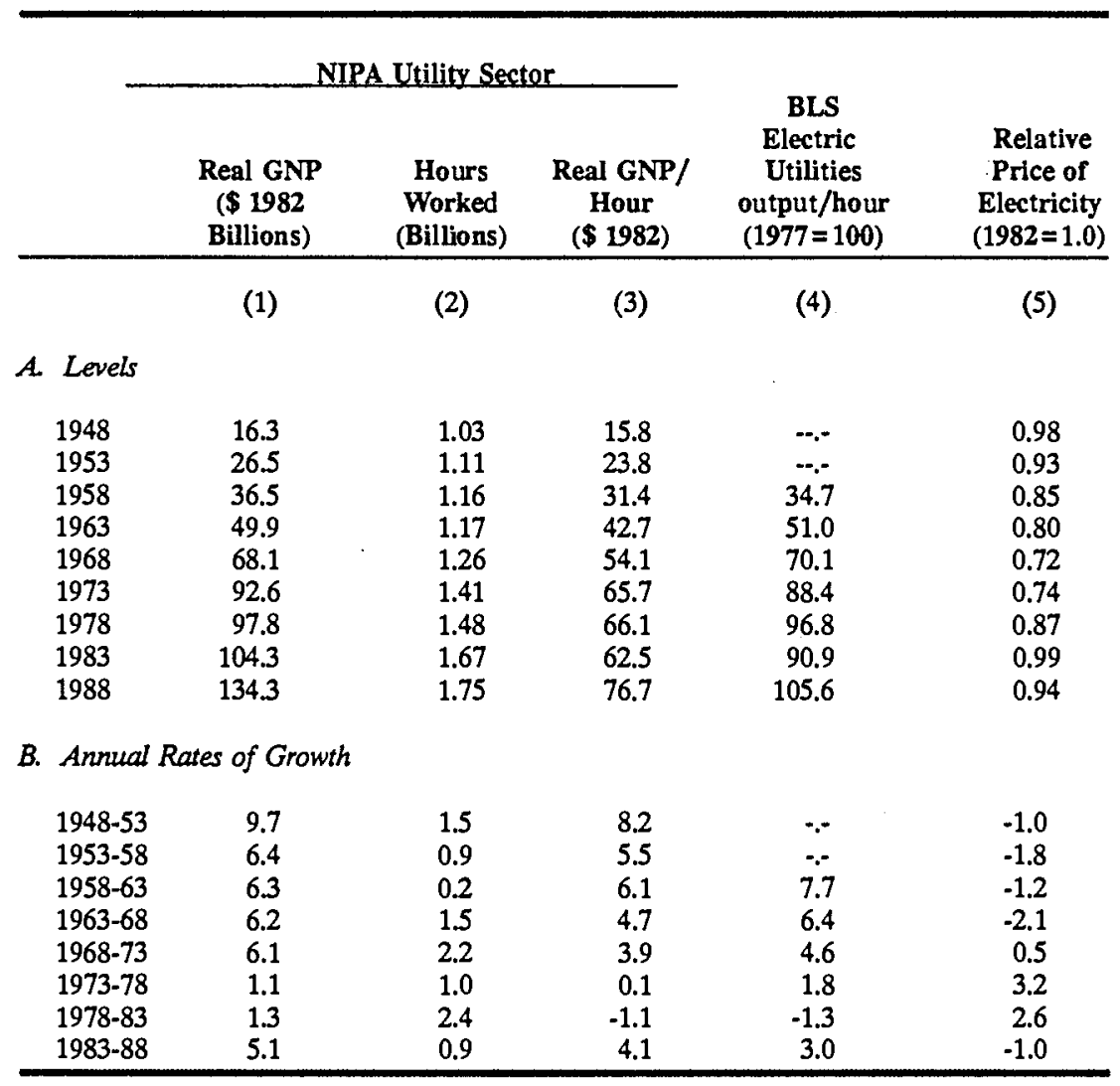

Sources by column: (1)-(3) and (5) from NIPA as follows, (1): 1948-73, Table 6.2, line 49, linked in 1977 to Survey of Current Business, January 1991, Table 6, line 49, p. 34; (2): Table 6.11, line 15; (3) = (1)/(2); (5) Table 7.10, line 50.

(4) uses the same sources as Table 1, col (2). 


\section{TABLE 3}

Output Per Employee, Annual Percentage Growth Rates, Selected Intervals, 1948-87

\begin{tabular}{|c|c|c|c|c||}
\hline From & To & $\begin{array}{c}\text { NIPA Utility } \\
\text { Sector }\end{array}$ & $\begin{array}{c}\text { BLS Utility } \\
\text { Sector }\end{array}$ & $\begin{array}{c}\text { All Plants in } \\
\text { Sample }\end{array}$ \\
\hline $1948-1950$ & $1957-1959$ & 6.7 & - & 7.8 \\
$1957-1959$ & $1966-1968$ & 5.3 & 7.0 & 7.3 \\
$1966-1968$ & $1972-1974$ & 3.9 & 4.8 & 2.8 \\
$1972-1974$ & $1978-1980$ & -0.4 & 1.6 & -1.7 \\
$1978-1980$ & $1985-1987$ & 0.5 & 0.1 & 0.4 \\
\hline
\end{tabular}

Sources by column: (1) Output, same sources as Table 2, col. (1); employees from NIPA Table 6.10B.

(2) Same as Table 2, col. (4).

(3) New data set developed for this paper, see Data Appendix. 


\section{TABLE 4}

Selected Characteristics of

New Plants and All Plants,

Selected Intervals, 1948-1987

\begin{tabular}{|c|c|c|c|c|c|c|c|c|}
\hline & \multicolumn{2}{|c|}{$\begin{array}{c}\text { Average Annual } \\
\text { Number of } \\
\text { Plants } \\
\end{array}$} & \multicolumn{2}{|c|}{ 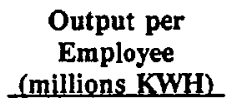 } & \multicolumn{2}{|c|}{$\begin{array}{l}\text { Average } \\
\text { Capacity }\end{array}$} & \multicolumn{2}{|c|}{$\begin{array}{c}\text { Average } \\
\text { Utilization Rate } \\
\text { (percent) }\end{array}$} \\
\hline & New & All & New & All & New & All & New & All \\
\hline & (1) & (2) & (3) & (4) & (5) & (6) & (7) & (8) \\
\hline $1948-50$ & 11 & 70 & 8.20 & 6.03 & 85 & 139 & 64 & 62 \\
\hline $1951-53$ & 10 & 105 & 11.01 & 8.13 & 121 & 168 & 67 & 64 \\
\hline $1954-56$ & 9 & 137 & 20.39 & 10.63 & 259 & 219 & 59 & 59 \\
\hline $1957-59$ & 8 & 157 & 22.53 & 12.18 & 221 & 254 & 65 & 54 \\
\hline $1960-62$ & 5 & 174 & 29.68 & 14.63 & 325 & 324 & 62 & 51 \\
\hline $1963-65$ & 8 & 188 & 29.50 & 18.95 & 347 & 381 & 61 & 53 \\
\hline $1966-68$ & 6 & 203 & 39.15 & 23.54 & 651 & 462 & 59 & 57 \\
\hline $1969-71$ & 6 & 216 & 33.90 & 26.00 & 578 & 561 & 48 & 57 \\
\hline $1972-74$ & 8 & 240 & 30.87 & 27.78 & 862 & 681 & 44 & 53 \\
\hline $1975-77$ & 11 & 260 & 30.40 & 27.16 & 749 & 769 & 42 & 47 \\
\hline $1978-80$ & 8 & 270 & 18.82 & 25.09 & 818 & 834 & 42 & 47 \\
\hline $1981-83$ & 5 & 228 & 20.33 & 26.06 & 794 & 1009 & 46 & 47 \\
\hline $1984-85$ & 4 & 197 & 18.46 & 25.71 & 946 & 1174 & 46 & 47 \\
\hline $1986-87$ & 2 & 194 & 12.77 & 25.56 & 921 & 1195 & 35 & 47 \\
\hline
\end{tabular}

Source: New data set developed for this paper, see Data Appendix. 


\section{TABLE 5}

\section{Equations Explaining The Log of Heat Rate by Plant, $1948-87$}

\begin{tabular}{|c|c|c|c|}
\hline & All Fuels & Coal Using & Noncoal Using \\
\hline & (1) & (2) & (3) \\
\hline 1. Log Capacity & $-0.084=*$ & $-0.083^{* *}$ & $-0.078 * *$ \\
\hline 2. Log Utilization & $-0.127 * *$ & $-0.147^{* *}$ & $-0.104^{* *}$ \\
\hline 3. Relative Price & $-0.094 * \approx$ & $-0.163^{* *}$ & $-0.039 * *$ \\
\hline 4. Number Units & $0.016^{* *}$ & $0.011^{* *}$ & $0.024^{*=}$ \\
\hline $\begin{array}{l}\text { 5. Vintage } \\
\text { a) All Vintages } \\
\text { b) } 1968-87 \text { Shift }\end{array}$ & $\begin{array}{r}-0.002 * \\
0.007 *\end{array}$ & $\begin{array}{r}-0.003^{* *} \\
0.008^{*}\end{array}$ & $\begin{array}{c}-0.002^{* *} \\
0.002\end{array}$ \\
\hline $\begin{array}{l}\text { 6. Time } \\
\text { a) All Years } \\
\text { b) } 1968-87\end{array}$ & $\begin{array}{r}-0.008 * * \\
0.017 * *\end{array}$ & $\begin{array}{r}-0.013^{* *} \\
0.025^{* *}\end{array}$ & $\begin{array}{r}-0.003^{* *} \\
0.007^{* *}\end{array}$ \\
\hline $\begin{array}{l}\text { 7. Fuel Type } \\
\text { a) Coal Using } \\
\text { b) Oil Only } \\
\text { c) Gas Only }\end{array}$ & $\begin{array}{r}-0.001 * * \\
0.029 * * \\
-0.027 *\end{array}$ & -...- & $\begin{array}{l}-. .006 \\
-0.018 * *\end{array}$ \\
\hline $\begin{array}{l}\overline{\mathrm{R}}^{2} \\
\text { Standard Error } \\
\text { Observations }\end{array}$ & $\begin{array}{r}0.649 \\
0.124 \\
6857\end{array}$ & $\begin{array}{r}0.516 \\
0.130 \\
4232\end{array}$ & $\begin{array}{l}0.586 \\
0.099 \\
2623\end{array}$ \\
\hline
\end{tabular}

Notes: $\quad$ Asterisks indicate 5 percent (") or 1 percent (") significance levels.

All equations also include five location dummy variables and two construction-type dummy variables, as well as a constant term. 


\section{TABLE 6}

\section{Equations Explaining the Log of Employment}

by Plant $1948-87$

\begin{tabular}{|c|c|c|c|}
\hline & All Fuels & Coal Using & Noncoal Using \\
\hline & (1) & (2) & (3) \\
\hline 1. Log Capacity & $0.539 * *$ & $0.554^{* *}$ & $0.453^{* *}$ \\
\hline 2. Log Utilization & $0.120^{* *}$ & $0.051 * *$ & $0.032 * *$ \\
\hline 3. Heat Rate Residual & $0.219 * *$ & $0.186^{* *}$ & $0.508 * *$ \\
\hline 4. Number Units & $0.061 * *$ & $0.060^{* *}$ & $0.073^{* *}$ \\
\hline $\begin{array}{l}\text { 5. Vintage } \\
\text { a) All Vintages } \\
\text { b) 1968-87 Shift }\end{array}$ & $\begin{array}{r}-0.015^{* *} \\
0.032 * *\end{array}$ & $\begin{array}{r}-0.014 * * \\
0.031\end{array}$ & $\begin{array}{l}-0.011 * * \\
-0.012 * *\end{array}$ \\
\hline $\begin{array}{l}\text { 6. Time } \\
\text { a) All Years } \\
\text { b) } 1968-87\end{array}$ & $\begin{array}{r}-0.027 * * \\
0.047 * *\end{array}$ & $\begin{array}{c}-0.029 * * \\
0.053^{* *}\end{array}$ & $\begin{array}{r}-0.024^{* *} \\
0.032^{*}\end{array}$ \\
\hline $\begin{array}{l}\text { 7. Fuel Type } \\
\text { a) Coal Using } \\
\text { b) Oil Only } \\
\text { c) Gas Only }\end{array}$ & $\begin{array}{r}-0.004^{* *} \\
-0.188^{* *} \\
-0.213^{* *}\end{array}$ & $\begin{array}{l}\because \cdots \\
-\cdots \\
-\cdots\end{array}$ & $\begin{array}{l}-.-0 \\
-0.002 \\
-0.115^{*}\end{array}$ \\
\hline $\begin{array}{l}\overline{\mathrm{R}}^{2} \\
\text { Standard Error } \\
\text { Observations }\end{array}$ & $\begin{array}{r}0.782 \\
0.373 \\
6674\end{array}$ & $\begin{array}{r}0.792 \\
0.357 \\
4181\end{array}$ & $\begin{array}{l}0.788 \\
0.312 \\
2491\end{array}$ \\
\hline
\end{tabular}

Notes: $\quad$ Asterisks indicate 5 percent (") or 1 percent (**) significance levels.

All equations also include five location dummy variables and two construction-type dummy variables, as well as a constant term. 


\section{TABLE 7}

\section{Equations Explaining the Log of Employment}

by Plant with Vintage Averaging, 1948-87

\section{All Fuels}

(1)

$0.580^{* *}$

$0.088^{* *}$

0.074

$0.061^{* *}$

$-0.030^{*}=$

$0.049=*$

b) $1968-87$ Shift

6. Time
a) All Years
b) $1968-87$
$-0.014^{* *}$
$0.036^{* *}$
$-0.019^{* *}$
$0.045^{* *}$
$-0.011^{* *}$
$0.023^{* *}$

7. Fuel
a) Coal Using
b) Oil Only
c) Gas Only

$$
\overline{\mathbf{R}}^{2}
$$

Standard Error

Observations
$-0.343^{*}$
$-0.065 *$
$-0.051^{*}$

0.802

0.359

5031

$\begin{array}{ll}\because \cdots & \because \cdots \\ -\cdots & -0.058^{* *} \\ -\cdots & -0.112^{* *}\end{array}$

0.805
0.357
3036

0.790

0.313

Notes: $\quad$ Asterisks indicate 5 percent $(*)$ or 1 percent $(* *)$ significance levels.

All equations also include five location dummy variables and two construction-type dummy variables, as well as a constant term. 


\section{TABLE 8}

Equations Explaining the Log of Employment by Plant over Split Sample Periods, 1948-67 and 1968-87

\begin{tabular}{|c|c|c|c|c|}
\hline & \multicolumn{2}{|c|}{ Coal Using } & \multicolumn{2}{|c|}{ Noncoal Using } \\
\hline & $1948-67$ & $1968-87$ & $1948-67$ & $1968-87$ \\
\hline 1. Log Capacity & $0.541 * *$ & $0.665^{* *}$ & $0.409^{* *}$ & $0.522^{* *}$ \\
\hline 2. Log Utilization & $-0.080^{*}$ & $0.150^{* *}$ & 0.001 & 0.022 \\
\hline $\begin{array}{l}\text { 3. Heat Rate } \\
\text { Residual }\end{array}$ & $0.674^{* *}$ & -0.058 & $0.861^{* *}$ & 0.260 \\
\hline 4. Units & $0.083^{* *}$ & $0.053^{* *}$ & $0.089 *$ & $0.059^{* *}$ \\
\hline $\begin{array}{l}\text { 5. Average Vintage } \\
\text { a. All Vintages } \\
\text { b. } 1968-87\end{array}$ & $\begin{array}{c}-0.028 * * \\
-. .\end{array}$ & $\begin{array}{r}-0.029^{* *} \\
0.043^{* *}\end{array}$ & $\begin{array}{c}-0.016^{* *} \\
-. \cdots\end{array}$ & $\begin{array}{c}-0.029 * * \\
0.018 *\end{array}$ \\
\hline $\begin{array}{l}\text { 6. Time } \\
\text { a. All Years } \\
\text { b. } 1968-87\end{array}$ & $\begin{array}{c}-0.013^{* *} \\
-.--\end{array}$ & $\begin{array}{l}0.027^{* *} \\
-\cdots\end{array}$ & $\begin{array}{c}-0.012^{* *} \\
-. . \cdots\end{array}$ & $\begin{array}{c}-0.012^{* *} \\
-. \cdots\end{array}$ \\
\hline $\begin{array}{l}\text { 7. Fuel } \\
\text { a. Coal Using } \\
\text { b. Oil Only } \\
\text { C. Gas Only }\end{array}$ & $\because-$ & $\begin{array}{l}-\because- \\
-\cdots \\
-\cdots\end{array}$ & $\begin{array}{l}-.0 .025 \\
-0.147^{\star *}\end{array}$ & $\begin{array}{l}0.057^{*} \\
-0.116^{* *}\end{array}$ \\
\hline $\begin{array}{l}\overline{\mathrm{R}}^{2} \\
\text { Standard Error } \\
\text { Observations }\end{array}$ & $\begin{array}{c}0.834 \\
0.287 \\
984\end{array}$ & $\begin{array}{r}0.763 \\
0.373 \\
2049\end{array}$ & $\begin{array}{c}0.837 \\
0.236 \\
511\end{array}$ & $\begin{array}{r}0.762 \\
0.330 \\
1484\end{array}$ \\
\hline
\end{tabular}

Notes: $\quad$ Asterisks indicate 5 percent (") or 1 percent (") significance levels.

All equations also include five location dummy variables and two construction-type dummy variables, as well as a constant term. 


\section{TABLE 9}

Average Heat and Utilization Rates

by Fuel Type, Selected Intervals,

New Plants in First Full Year of Operation

\begin{tabular}{|c|c|c|c|c|c|c|c|c|}
\hline & $\begin{array}{l}1948- \\
1952\end{array}$ & $\begin{array}{l}1953- \\
1957 \\
\end{array}$ & $\begin{array}{l}1958- \\
1962\end{array}$ & $\begin{array}{l}1963- \\
1967\end{array}$ & $\begin{array}{l}1968- \\
1972\end{array}$ & $\begin{array}{l}1973- \\
1977\end{array}$ & $\begin{array}{l}1978- \\
1982\end{array}$ & $\begin{array}{l}1983- \\
1986\end{array}$ \\
\hline 1. Heat Rate & 12.3 & 10.5 & 10.0 & 9.8 & 10.0 & 10.4 & 10.6 & 10.6 \\
\hline a. Coal Using & 12.3 & 10.4 & 9.9 & 9.5 & 9.9 & 10.5 & 10.5 & 10.6 \\
\hline b. Oil Only & 11.6 & 10.5 & 10.1 & 9.2 & 9.3 & 10.0 & 10.9 & $\because \cdot$ \\
\hline c. Gas Only & 12.7 & 11.6 & 10.5 & 10.3 & 10.2 & 10.5 & 10.7 & $\cdots$ \\
\hline $\begin{array}{l}\text { 2. Utilization } \\
\text { Rate }\end{array}$ & 65.1 & 60.6 & 64.6 & 61.7 & 48.4 & 42.1 & 44.5 & 41.5 \\
\hline a. Coal Using & 66.8 & 56.1 & 66.9 & 63.7 & 47.4 & 47.3 & 48.4 & 41.5 \\
\hline b. Oil Only & 65.6 & 50.7 & 56.3 & 68.7 & 52.4 & 34.4 & 18.8 & $\cdots$ \\
\hline c. Gas Only & 66.7 & 61.9 & 55.3 & 58.9 & 46.6 & 38.0 & 57.1 &..- \\
\hline
\end{tabular}




\section{TABLE 10}

Equations Explaining the Log of Employment

With Interaction Effects, Coal-Using Plants,

1948-87

\begin{tabular}{|c|c|c|c|c|}
\hline & $\begin{array}{c}\text { Basie } \\
\text { Equation }\end{array}$ & $\begin{array}{l}\text { Vintage } \\
\text { Interaetion }\end{array}$ & $\begin{array}{c}\text { Signifieant } \\
\text { Interaetion } \\
\text { Terms }\end{array}$ & $\begin{array}{l}\text { Add Year } \\
\text { Interaetion }\end{array}$ \\
\hline & (1) & (2) & (3) & $(4)$ \\
\hline 1. Log Capacity & $0.592^{* *}$ & $0.700^{* *}$ & $0.705^{*}$ & $0.623^{* *}$ \\
\hline 2. Log Utilization & $0.082^{* *}$ & 0.067 & $0.105 * *$ & -0.007 \\
\hline 3. Heat Rate Residual & 0.004 & -0.224 & $-0.174^{* *}$ & $-0.294^{* *}$ \\
\hline 4. Number of Units & $0.067^{* *}$ & $0.069^{* *}$ & $0.069^{* *}$ & $0.062^{* *}$ \\
\hline $\begin{array}{l}\text { 5. Average Vintage } \\
\text { a. All } \\
\text { b. 1968-87 Shift } \\
\text { c. } 1 * 5 a \text { (VCAP) } \\
\text { d. } 1 \text { : 5b (VSCAP) } \\
\text { e. } 2 * 5 a \text { (VUT) } \\
\text { f. } 2 * 5 b \text { (VSUT) } \\
\text { g. } 3 * \text { Sa (VHR) } \\
\text { h. } 3 * 5 b \text { (VSHR) }\end{array}$ & $\begin{array}{l}-0.026^{* *} \\
0.047^{* *} \\
--- \\
-\because- \\
--- \\
--- \\
--- \\
-\cdots\end{array}$ & $\begin{array}{c}-0.080^{* *} \\
0.183^{* *} \\
0.009^{* *} \\
-0.020^{* *} \\
-0.001 \\
0.013 \\
-0.006 \\
0.122^{* *}\end{array}$ & $\begin{array}{r}-0.082^{* *} \\
0.186^{* *} \\
0.009^{* *} \\
-0.022^{* *} \\
\because-- \\
-.- \\
--- \\
0.119^{* *}\end{array}$ & $\begin{array}{l}-0.056^{* *} \\
0.193^{* *} \\
0.004^{* *} \\
-0.022^{* *} \\
-\ldots \\
-\cdots \\
-\cdots \\
0.074 * *\end{array}$ \\
\hline $\begin{array}{l}\text { 6. Time } \\
\text { a. All } \\
\text { b. } 1968-87 \text { Shift } \\
\text { c. } 1 * 6 \mathrm{~b} \text { (TSCAP) } \\
\text { d. } 2 * 6 \mathrm{~b} \text { (TSUTTL) } \\
\text { e. } 3 * 6 \mathrm{~b} \text { (TSHR) }\end{array}$ & $\begin{array}{l}-0.019^{* *} \\
0.045^{* *} \\
-.-- \\
-.- \\
-.-\end{array}$ & $\begin{array}{l}-0.014^{* *} \\
0.038^{* *} \\
\therefore- \\
\therefore- \\
-\because-\end{array}$ & $\begin{array}{l}-0.013 \\
0.038^{* *} \\
-.-- \\
-.- \\
-.-\end{array}$ & $\begin{array}{l}-0.011^{* *} \\
-0.012 \\
0.009 * * \\
0.013^{* *} \\
0.039 * *\end{array}$ \\
\hline $\begin{array}{l}\overrightarrow{\mathrm{R}}^{2} \\
\text { Standard Error } \\
\text { Observations }\end{array}$ & $\begin{array}{r}0.805 \\
0.357 \\
3036\end{array}$ & $\begin{array}{c}0.811 \\
0.351 \\
3036 \\
\end{array}$ & $\begin{array}{r}0.811 \\
0.351 \\
3036\end{array}$ & $\begin{array}{r}0.815 \\
0.348 \\
3036 \\
\end{array}$ \\
\hline
\end{tabular}

Notes: $\quad$ Asterisks indicate 5 percent $\left({ }^{\circ}\right)$ or 1 percent $\left({ }^{\circ}\right)$ significance levels.

All equations also include five location dummy variables and two construction-type dummy variables, as well as a constant term. 


\section{TABLE 11}

Sources of Productivity Growth, All Coal-Using Plants, By Decade Annual Percentage Rates of Change, Using Equation from Table 10, column (4)

\begin{tabular}{|c|c|c|c|c|}
\hline & $\begin{array}{l}1948- \\
1958 \\
\end{array}$ & $\begin{array}{l}1958- \\
1968 \\
\end{array}$ & $\begin{array}{l}1969- \\
1978\end{array}$ & $\begin{array}{c}1978- \\
1987\end{array}$ \\
\hline A. Actual & 8.83 & 4.75 & -1.88 & -0.35 \\
\hline B. Predicied & 10.43 & 4.78 & -1.86 & -0.43 \\
\hline \multicolumn{5}{|l|}{ C. Contribution of } \\
\hline $\begin{array}{l}\text { 1. Capacity } \\
\text { a. Effect on Output } \\
\text { b. Minus Capacity Effect on Employment } \\
\text { c. Minus VCAP \& VSCAP Effects on Employme nt } \\
\text { d. Minus TSCAP Effect on Employment }\end{array}$ & $\begin{array}{r}3.91 \\
10.94 \\
-6.82 \\
-0.21 \\
-.\end{array}$ & $\begin{array}{r}2.71 \\
8.94 \\
.5 .57 \\
-0.66 \\
-.-\end{array}$ & $\begin{array}{r}-2.95 \\
5.11 \\
-3.18 \\
0.89 \\
-5.77\end{array}$ & $\begin{array}{r}-0.30 \\
6.52 \\
-4.06 \\
4.10 \\
-6.89\end{array}$ \\
\hline $\begin{array}{l}\text { 2. Utilization } \\
\text { a. Effect on Output } \\
\text { b. Minus Utilization Effect on Employment } \\
\text { c. Minus TSUT Effect on Employment }\end{array}$ & $\begin{array}{l}3.35 \\
3.33 \\
0.02 \\
-. .\end{array}$ & $\begin{array}{l}-0.45 \\
-0.45 \\
-0.00 \\
-.0\end{array}$ & $\begin{array}{l}-1.90 \\
-2.83 \\
-0.02 \\
0.95\end{array}$ & $\begin{array}{l}1.43 \\
0.63 \\
0.00 \\
0.80\end{array}$ \\
\hline $\begin{array}{l}\text { 3. Heat Rate Residual } \\
\text { a. Minus HR Effect. on Employment } \\
\text { b. Minus VSHR Effect on Employment } \\
\text { c. Minus TSHR Effect on Employment }\end{array}$ & $\begin{array}{l}0.08 \\
0.08 \\
\because .0 \\
\cdots\end{array}$ & $\begin{array}{l}0.22 \\
0.22 \\
-. .-\end{array}$ & $\begin{array}{l}-0.16 \\
-0.02 \\
-0.08 \\
-0.06\end{array}$ & $\begin{array}{r}0.37 \\
-0.09 \\
0.29 \\
0.17\end{array}$ \\
\hline 4. Units & -0.53 & -0.14 & 0.05 & -0.21 \\
\hline $\begin{array}{l}\text { 5. Average Vintage } \\
\text { a. Basic Effect } \\
\text { b. } 1968-87 \text { Shift }\end{array}$ & $\begin{array}{l}2.90 \\
2.90 \\
-\cdots\end{array}$ & $\begin{array}{l}2.75 \\
2.75 \\
-.-\end{array}$ & $\begin{array}{r}0.51 \\
3.58 \\
.3 .07\end{array}$ & $\begin{array}{r}-2.09 \\
3.30 \\
-5.39\end{array}$ \\
\hline $\begin{array}{l}\text { 6. Time } \\
\text { a. Basic Effect } \\
\text { b. } 1968-87 \text { Shift }\end{array}$ & $\begin{array}{l}1.10 \\
1.10 \\
-.-\end{array}$ & $\begin{array}{l}1.10 \\
1.10 \\
-.\end{array}$ & $\begin{array}{r}-0.10 \\
1.10 \\
-1.20\end{array}$ & $\begin{array}{r}-0.10 \\
1.10 \\
.1 .20\end{array}$ \\
\hline 7. Dummy Variables and Other & -0.38 & $-1,41$ & 2.69 & 0.50 \\
\hline
\end{tabular}




\section{TABLE 12}

Equations Explaining the Log of Employment

Allowing for the Establishment and Firm Erfects

Unedited Sample for Coal Using Plants, 1948-87

\begin{tabular}{|c|c|c|c|c|c|c|}
\hline & \multirow[t]{2}{*}{$\begin{array}{c}\text { Basle } \\
\text { Eouation }\end{array}$} & \multicolumn{2}{|c|}{$\begin{array}{c}\text { Equation with } \\
\text { Establishment } \\
\text { Effects }\end{array}$} & \multicolumn{3}{|c|}{$\begin{array}{l}\text { Equation with } \\
\text { Establishment and } \\
\text { and Frm Erfecis }\end{array}$} \\
\hline & & $\begin{array}{l}\text { "Withla" } \\
\text { Effect }(\theta)\end{array}$ & $\begin{array}{l}\text { "Between" } \\
\text { Erfect ( } \phi)\end{array}$ & $\begin{array}{l}\text { "Withlo" } \\
\text { Effect }(\beta)\end{array}$ & $\begin{array}{c}\text { "Betw. Estab." } \\
\text { Effect }(\phi)\end{array}$ & $\begin{array}{l}\text { "Betw. Firm" } \\
\text { Effect }(\theta)\end{array}$ \\
\hline & (1) & (2) & (3) & (4) & (5) & $(6)$ \\
\hline 1. Log Capacity & $0.594^{\circ *}$ & $0.590^{\circ \bullet}$ & $-0.003^{\circ *}$ & $0.601^{\circ 0}$ & $0.071^{*}$ & $0.101^{\bullet \bullet}$ \\
\hline 2 Log Utilization & $0.068^{\bullet \bullet}$ & $0.093^{\circ \bullet}$ & -0.068 & $0.077^{\bullet \bullet}$ & $-0.105^{\oplus} \bullet$ & 0.058 \\
\hline 3. Log Heat Rate & $0.003^{* 14}$ & $-0.076^{\circ}$ & $0.5599^{\circ 4}$ & -0.074 & $0.739^{\bullet \bullet}$ & 0.323 \\
\hline $\begin{array}{l}\text { 4. Number of } \\
\text { Units }\end{array}$ & $0.066^{* *}$ & 0.034 & 0.041 & $0.042^{\circ}$ & -0.012 & $0.129^{* *}$ \\
\hline $\begin{array}{l}\text { 5. Vintage } \\
\text { a) All } \\
\text { b) } 1968-87\end{array}$ & $\begin{array}{l}-0.026^{*} \\
0.046^{\circ}\end{array}$ & $\because-$ & $-0.026^{\circ}$ & $\because-$ & $\begin{array}{l}-0.021^{\circ} \\
0.044\end{array}$ & $\because-$ \\
\hline $\begin{array}{l}\text { 6. Time } \\
\text { a) All Years } \\
\text { b) } 1968-87\end{array}$ & $\begin{array}{l}-0.019^{\infty} \\
0.046^{* *}\end{array}$ & $\begin{array}{c}-0.016^{\circ *} \\
0.044^{* 1}\end{array}$ & $\because$ & $\begin{array}{c}-0.016^{\circ} \\
0.043^{\circ \bullet}\end{array}$ & 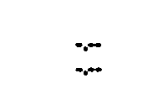 & $\therefore$ \\
\hline $\begin{array}{l}\overline{\mathbf{R}^{2}} \\
\text { Standard Error } \\
\text { Observations }\end{array}$ & $\begin{array}{l}0.807 \\
0.356 \\
2990^{4}\end{array}$ & & $\begin{array}{l}809 \\
354 \\
990^{\circ}\end{array}$ & & $\begin{array}{l}0.827 \\
0.337 \\
2990^{\circ}\end{array}$ & \\
\hline
\end{tabular}

Note: Asterisks indicate 5 percent (") or 1 percent (") significance levels. All equations also include five location dummy variables and two construction-type dummy variables, as well as a constant term.

a. Plants with fewer than two observations were excluded. 


\section{TABLE 13}

Summary Information on Outlier Plants

\begin{tabular}{|c|c|c|c|c|c|c|}
\hline & $\begin{array}{c}\text { Number } \\
\text { Telephoned }\end{array}$ & $\begin{array}{l}\text { Average } \\
\text { Viatage }\end{array}$ & $\begin{array}{l}\text { Averape } \\
\text { Capacity }\end{array}$ & $\begin{array}{c}\text { Average } \\
\text { Actual } \\
\text { Employment }\end{array}$ & $\begin{array}{c}\text { Average } \\
\text { Predicted } \\
\text { Employment }\end{array}$ & $\begin{array}{c}\text { Lo (Act.) } \\
\text { minus } \\
\text { Ln (Pred.) }\end{array}$ \\
\hline \multicolumn{7}{|l|}{$\begin{array}{l}\text { Outliers telephoned in } \\
1982 \text {, averages for } 1978\end{array}$} \\
\hline 17 positive outliers & 12 & 1963 & 1179 & 366 & 126 & 1.07 \\
\hline 12 negative outliers & 0 & 1946 & 622 & 96 & 178 & -0.62 \\
\hline \multicolumn{7}{|l|}{$\begin{array}{l}\text { Outliers telephoned in } \\
\text { 1990, averages for } 1987\end{array}$} \\
\hline 15 positive outliers & 4 & 1968 & 1473 & 470 & 224 & 0.74 \\
\hline 15 negative outliers & 8 & 1966 & 898 & 70 & 169 & -0.88 \\
\hline
\end{tabular}

